\title{
Novel Investigations of Flavonoids as Chemopreventive Agents for Hepatocellular Carcinoma
}

\author{
Chen-Yi Liao, ${ }^{1,2}$ Ching-Chang Lee, ${ }^{1}$ Chi-chang Tsai, ${ }^{1}$ Chao-Wen Hsueh, ${ }^{1}$ \\ Chih-Chiang Wang, ${ }^{1}$ I-Hung Chen, ${ }^{1}$ Ming-Kai Tsai, ${ }^{1}$ Mei-Yu Liu, ${ }^{1}$ An-Tie Hsieh, ${ }^{1}$ \\ Kuan-Jen Su, ${ }^{1}$ Hau-Ming Wu, ${ }^{1}$ Shih-Chung Huang, ${ }^{1}$ Yi-Chen Wang, ${ }^{1}$ \\ Chien-Yao Wang, ${ }^{1}$ Shu-Fang Huang, ${ }^{1}$ Yen-Cheng Yeh, ${ }^{1}$ Ren-Jy Ben, ${ }^{1}$ \\ Shang-Tao Chien, ${ }^{3}$ Chin-Wen Hsu, ${ }^{4}$ and Wu-Hsien Kuo ${ }^{1}$ \\ ${ }^{1}$ Department of Internal Medicine, Kaohsiung Armed Forces General Hospital, Kaohsiung 80284, Taiwan \\ ${ }^{2}$ Department of Internal Medicine, Tri-Service General Hospital, National Defense Medical Center, \\ No. 325, Section 2, Cheng-Kung Road, Neihu, Taipei 114, Taiwan \\ ${ }^{3}$ Department of Pathology, Kaohsiung Armed Forces General Hospital, Kaohsiung 80284, Taiwan \\ ${ }^{4}$ Department of General Surgery, Kaohsiung Armed Forces General Hospital, Kaohsiung 80284, Taiwan \\ Correspondence should be addressed to Wu-Hsien Kuo; wuhsienku@gmail.com
}

Received 2 September 2015; Accepted 19 October 2015

Academic Editor: Javier G. Gallego

Copyright ( $\odot 2015$ Chen-Yi Liao et al. This is an open access article distributed under the Creative Commons Attribution License, which permits unrestricted use, distribution, and reproduction in any medium, provided the original work is properly cited.

We would like to highlight the application of natural products to hepatocellular carcinoma (HCC). We will focus on the natural products known as flavonoids, which target this disease at different stages of hepatocarcinogenesis. In spite of the use of chemotherapy and radiotherapy in treating HCC, patients with HCC still face poor prognosis because of the nature of multidrug resistance and toxicity derived from chemotherapy and radiotherapy. Flavonoids can be found in many vegetables, fruits, and herbal medicines that exert their different anticancer effects via different intracellular signaling pathways and serve as antioxidants. In this review, we will discuss seven common flavonoids that exert different biological effects against HCC via different pathways.

\section{Introduction}

1.1. Hepatocellular Carcinoma and Current Treatment. Hepatocellular carcinoma (HCC) accounts for approximately $5.6 \%$ of all tumors [1]. More than $80 \%$ of patients with liver cancer are diagnosed with HCC [2], which is resistant to most conventional therapies, such as chemotherapy and radiotherapy. Although HCC is the sixth most common neoplasm worldwide, its grave prognosis makes it the third leading cause of cancer-related mortality, responsible for approximately 600,000 deaths annually [3-5]. Hepatitis B and hepatitis $\mathrm{C}$ viruses are responsible for the highest frequencies of HCC occurrence in endemic areas, such as sub-Saharan Africa and far eastern Asia. In addition to these infections, alcohol consumption and exposure to dietary carcinogens, including aflatoxin B1 and nitrosamines, are other widely recognized etiological agents of HCC [6]. Carcinogenesis usually occurs as a result of chemical or biological damage to normal cells in a multistep and multifactor process composed of genetic derangement, aberrant signal transduction, and protein kinase activation. These processes contribute to the three stages of cancer development, which are known as initiation, promotion, and progression. Among the three stages, the promotion stage is reversible and appears to be the most appropriate target stage for chemopreventive intervention [7].

Hepatocarcinogenesis usually takes place under circumstances that include chronic viral infection or inflammation with further regeneration and cirrhosis. Influences, such as oxidative stress, which are caused by free radicals and immune responses, may contribute to DNA damage [811]. Current therapies targeting HCC, such as chemotherapy, surgical resection, transcatheter arterial embolization, percutaneous ablation therapy, liver transplant, and target 
therapy, do not always lead to optimal patient outcomes. Only surgery offers a cure, but tumor resection is feasible for $<15 \%$ of patients. Even among those treated with curative intent, relapse rates are up to $50 \%$ [12]. HCC is often undetectable until late in the progression of the disease, and chemotherapy in the terminal stage does not usually exert much influence. Chemotherapy also has undesirable side effects, particularly in normal tissues with potent proliferative activity. Chemotherapy also adds little to the overall survival of patients with HCC because of the lower sensitivity of HCC cells, the emergence of drug resistance, and insufficient chemotherapeutic doses due to impaired liver function. Likewise, hepatectomy and liver transplantation can be curative, but high recurrence rates and subsequent low survival rates are still being reported $[1,2,10,12]$. Palliative treatments associated with survival benefits include transcatheter arterial chemoembolization and sorafenib treatment. However, there is no consensus regarding the optimal treatment strategy [12].

Therefore, more effective therapeutic agents for treating HCC are desired, particularly specific agents that can target tumor cells instead of normal cells. The development of drugs that specifically target tumor cells or possess synergy with previous chemotherapeutic agents represents a common goal in drug development. Several clinical trials for HCC have been carried out with various therapeutic targets [13]. The aim of this review was to give an overview of the research in the field of flavonoids in HCC treatment and not only address the underlying mechanism of each flavonoid reported from several animal studies in vitro and in vivo on hepatoma cell lines [14-31] but also update its chemopreventive role on various targets $[15,22,25,32-43]$.

1.2. HCC and Flavonoids. Novel trends for comprehensive HCC therapy include chemoprevention induced by nature products, which is still under academic investigation. Chemoprevention is one of the strategies by which we can revert, suppress, or delay the response to carcinogens or even prevent carcinogenesis via the use of natural or synthetic chemical agents. Cancer chemopreventive agents are able to reduce the incidence of tumorigenesis by intervening in one or more of the stages of carcinogenesis: initiation, promotion, or progression. Many chemopreventive agents are derived from natural products, Chinese herbal medicines, and phytochemicals, namely, nonnutritive plant chemicals with protective or disease-preventive properties [44].

Natural products are nontoxic natural extracts or compounds that, compared with synthetic materials, generally produce fewer side effects; thus, they potentially provide an alternative or adjunct therapeutic option for patients with cancer.

In developing countries, approximately $35 \%$ of the prescribed drugs are derived from natural products, and over $60 \%$ of the anticancer drugs in clinical use originated from natural products [45], including plants, marine organisms, and microbes. Many investigations are being carried out worldwide to discover naturally occurring compounds that can suppress or prevent the progress of carcinogenesis, particularly in the field of HCC $[46,47]$. The anticancer effects of most natural products often do not kill cancer cells directly.
Rather, by regulating human immune function, they target the promotion stage by means of interrupting the cell cycle. This leads to the induction of apoptosis and differentiation, as well as the inhibition of cell growth and proliferation. These therapies may provide a second chance for the patient with terminal HCC and decrease HCC incidence in a preventive way. Recently, there has been a sustained growth of newly developed, effective compounds from natural products. The most often identified is the flavonoid family. The flavonoids are a group of plant secondary metabolites that comprise diverse classes of polyphenolic compounds found in fruits, vegetables, roots, stems, flowers, and beans, as well as beverages such as tea and wine, which can be ingested daily. These natural products were known for their beneficial effects on health long before flavonoids were isolated as the effective compounds. Attending to their molecular structures, flavonoids are usually divided into seven classes, including flavonols, flavanones, isoflavones, flavonols flavonolignans, and anthocyanidins. At the moment, more than 6,000 different natural flavonoids have been identified. Several studies have demonstrated that the increased taking of flavonoids is associated with several health-promoting properties, including a decreased risk of inflammation [48], hypertension [49], cardiovascular disease [50], allergic disease [51], and osteoporosis [52]. Some studies have also pointed out their antiviral [53-57] and antimicrobial properties [58, 59].

Studies of dietary flavonoids have revealed a broad spectrum of biological activities for these molecules, including the inhibition of cell proliferation in cell culture [46], induction of apoptosis [60], alteration of the activity of certain intracellular enzymes, and antioxidant properties [61]. Flavonoids are famous for their anticancer properties through multifactorial pathways [47]. The chemopreventive and chemotherapeutic effects of the flavonoids have been studied, and the most common effect of flavonoids is the scavenging of oxygen-derived free radicals. Other mechanisms focus on targeting the cancer promotion stage, the intracellular apoptotic pathway, and the cancer proliferation stage, including angiogenesis and metastasis $[62,63]$. Natural compounds have been investigated for anticancer activities against lung cancer [64], breast cancer [65], gastric cancer and esophageal cancer [66], hepatocellular cell carcinoma [14,67], colon cancer [68], prostate cancer [69], ovarian cancer [70], human cervical carcinoma [71], and leukemia [72]. In recent years, various flavonoids have been recognized as having potential protective activity against artificially induced-liver damage [24, 73, 74]. Accordingly, several studies have been conducted to investigate their chemopreventive abilities in HCC using various in vitro and in vivo methods [17-19, 25, 30, 34, 37, 43, 75-83].

\section{Methods}

In this paper, for the sake of clarity, we have researched the most common flavonoids that can affect HCC. Several reviews have provided major contributions to the current state of knowledge concerning the use of flavonoids for the treatment of liver cancer. The reports presented in the English language are reviewed to provide the full picture of the progression of the use of flavonoids against HCC. English 
<smiles>O=C(O[C@H]1Cc2c(O)cc(O)cc2O[C@@H]1c1cc(O)c(O)c(O)c1)c1cc(O)c(O)c(O)c1</smiles>

EGCG (flavanol)

(a)<smiles>O=c1cc(-c2ccccc2)oc2cc(O)c(O)c(O)c12</smiles>

(d)<smiles>O=c1c(O)c(-c2ccccc2)oc2cc(O)cc(O)c12</smiles>

Galangin (flavonol)

(b)<smiles>O=c1c(O)c(-c2ccc(O)c(O)c2)oc2cc(O)cc(O)c12</smiles>

(c)<smiles>COc1c(O)cc2oc(-c3ccccc3)cc(=O)c2c1O</smiles>

(e)<smiles>O=c1c(-c2ccc(O)cc2)coc2cc(O)cc(O)c12</smiles>

(f)<smiles>COc1cc(C2Oc3cc(C4Oc5cc(O)cc(O)c5C(=O)C4O)ccc3OC2CO)ccc1O</smiles>

(g)

Figure 1: Chemical structures of flavonoids that target HCC: EGCG (a), galangin (b), quercetin (c), baicalein (d), oroxylin A (e), genistein (f), and silibinin (g). EGCG: (-)-epigallocatechin-3-gallate; HCC: hepatocellular carcinoma.

literature searches were conducted through the Medline, Embase, Science Citation Index, Current Contents, and PubMed databases, as well as relevant articles from integrative and complementary medicine journals, such as Evidence Based Complementary and Alternative Medicine, until August 2015. After completing the searches of these English resources, the well-known flavonoids could be subclassified according to their structures. The seven common subclasses that have an effect on HCC are listed as flavanols [(-)epi-gallocatechin-3-gallate (EGCG)], flavanones (liquiritigenin, hesperidin, naringenin, and xanthohumol), flavones (apigenin, baicalein, catechin, casticin, chrysin, diosmin, nobiletin, luteolin, oroxylin $\mathrm{A}$, and wogonin), isoflavones (daidzein, equol, genistein, glabridin, puerarin, and tectorigenin), flavonols (fisetin, galangin, icariin, myricetin, kurarinol, and quercetin), anthocyanins, and flavonolignans (silibinin). Here we summarize the most common flavonoids, including EGCG, baicalein, oroxylin A, genistein, galangin, quercetin, and silibinin (Figure 1). The outline of the articles reviewed is presented in a Quality of Reporting of MetaAnalysis flow chart showing the number of studies screened and included in the meta-analysis (Figure 2) [84].

The search terms were "EGCG," "galangin," "quercetin," "baicalein," "oroxylin A," "genistein," "silibinin," "hepatocellular carcinoma," and "hepatoma." Restrictions were placed on the language of publication, and only articles in English were included. Studies lacking controls and case reports were excluded.

The exclusion and inclusion criteria for data extracted from the literature were the same as those in PubMed. These restrictions were put in place to have consistency among the reports reviewed. The aim of this review was to give an overview of research in the field of flavonoids in HCC 


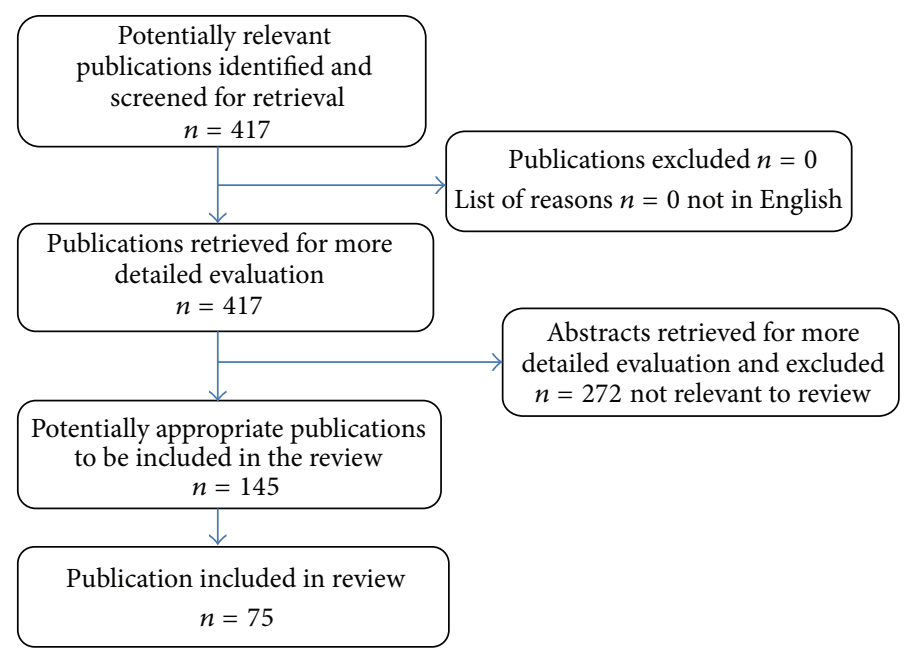

FIGURE 2: QUORUM algorithm of review of the flavonoids and hepatocellular carcinoma publications and abstracts.

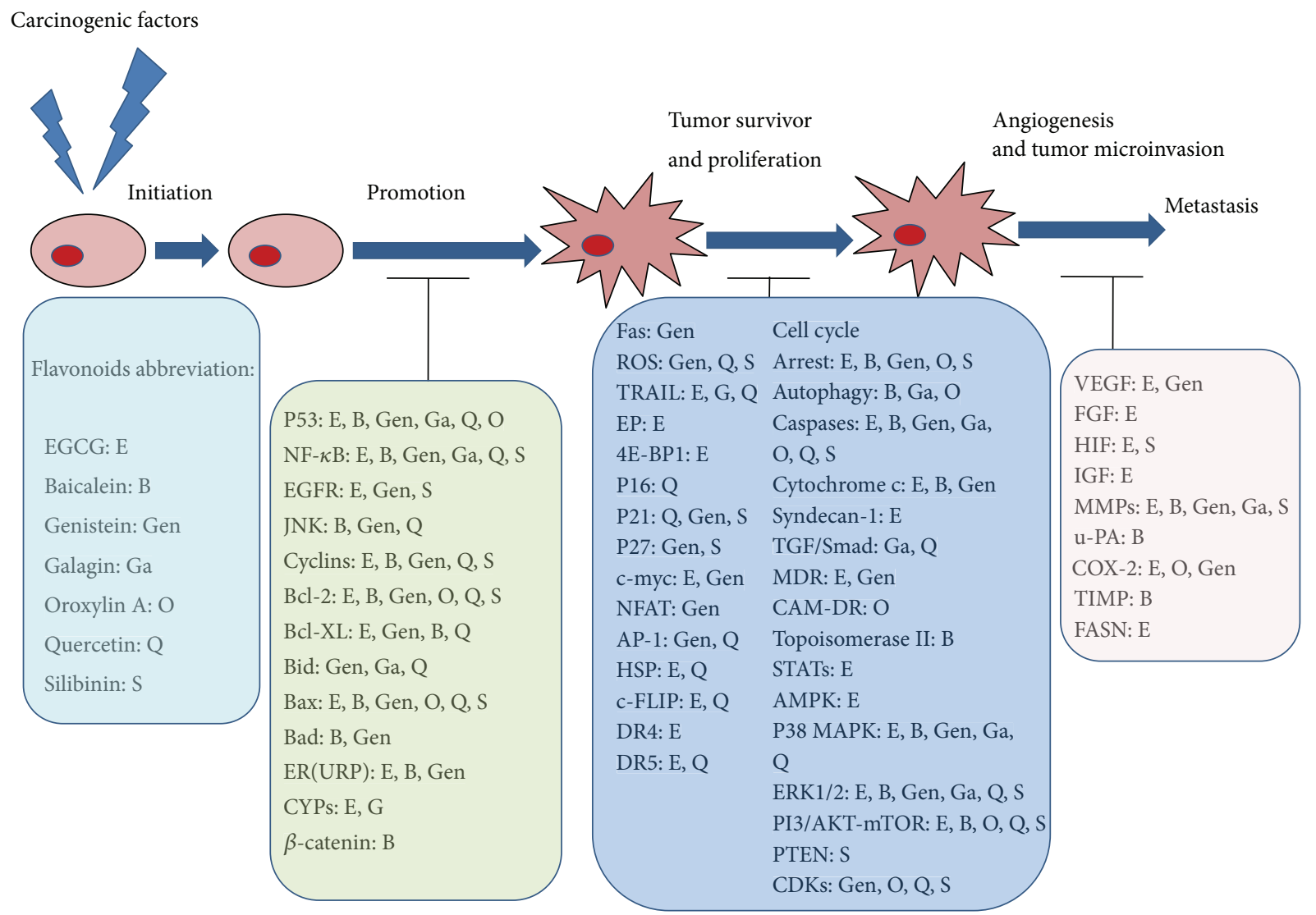

FIGURE 3: The different stages of HCC and the major targets modulated by various flavonoids. HCC: hepatocellular carcinoma; EGCG: (-)epigallocatechin-3-gallate.

treatment, not only to address the underlying mechanism of each flavonoid in several animal studies and hepatoma cell lines but also to update their chemopreventive roles on various targets.
Typical signal pathways targeted during HCC treatment via the above flavonoids will be reviewed below. The corresponding signal pathways and flavonoids are mapped in Figure 3 and summarized in Tables 1-7, respectively. 
TABLE 1: EGCG in HCC with possible mechanisms discussed in this paper.

\begin{tabular}{|c|c|c|c|c|c|}
\hline Subfamily & Flavonoids & Typical origin & $\begin{array}{l}\text { In vitro/in vivo } \\
\text { Cell lines/modes } \\
\text { Effective dose }\end{array}$ & Effects and related mechanisms & $\begin{array}{l}\text { Author (year) } \\
\text { References }\end{array}$ \\
\hline \multirow[t]{14}{*}{ Flavonol } & EGCG & $\begin{array}{l}\text { Green tea } \\
\text { red grapes and } \\
\text { red wines }\end{array}$ & $\begin{array}{l}\text { In vitro/in vivo } \\
\mathrm{HepG} 2 / \mathrm{SD} \text { rats by thioacetamide } \\
20 \mathrm{mg} / \mathrm{kg} / \mathrm{N} / \mathrm{A}\end{array}$ & $\begin{array}{l}\downarrow \alpha \text {-FP restoration of heparin } \\
\text { sulfate proteoglycans receptors, } \downarrow \\
\text { vascular invasion via } \downarrow \text { MMP-9, } \downarrow \\
\text { syndecan- } 1 \downarrow \text { FGF- } \text {, and } \downarrow \\
\text { fibrosis }\end{array}$ & $\begin{array}{l}\text { Darweish et al. } \\
\text { (2014) [36] }\end{array}$ \\
\hline & & & $\begin{array}{l}\text { In-vitro } \\
\text { Acrylamide-induced HepG2 cells } \\
10 \mu \mathrm{M}\end{array}$ & $\begin{array}{l}\downarrow \text { CYP2E1, } \downarrow \text { EGFR, } \downarrow \text { cyclin D1 } \\
\text { and } \downarrow \text { NF- } \kappa \text { B } \downarrow \text { growth by } \\
\text { affecting the cell cycle, and } \uparrow \\
\text { apoptosis }\end{array}$ & $\begin{array}{l}\text { Shan et al. } \\
\text { (2014) [17] }\end{array}$ \\
\hline & & & $\begin{array}{l}\text { In vitro } \\
\text { HepG2, SMMC7721 and SK-hep1 cells } \\
\text { IC50 74.7, 59.6, and } 61.3 \mu \mathrm{g} / \mathrm{mL}\end{array}$ & $\begin{array}{l}\uparrow \text { apoptosis by } \downarrow \text { PI3K/AKT } \\
\text { activity, } \downarrow \text { NF- } \kappa \text { B , and } \uparrow S \text { phase } \\
\text { arrest (in SMMC7721 cells) }\end{array}$ & $\begin{array}{l}\text { Shen et al. } \\
\text { (2014) [33] }\end{array}$ \\
\hline & & & $\begin{array}{l}\text { In vitro } \\
\text { HepG2 cells } \\
70 \mu \mathrm{g} / \mathrm{mL}\end{array}$ & $\begin{array}{l}\uparrow \text { TRAIL-induced apoptosis via } \uparrow \\
\text { caspase- } 3 \text { activity, } \uparrow \text { DR } 4 \uparrow \text { DR5 } \\
\text { expression, and } \downarrow \text { Bcl-2 } \\
\text { expression and } \downarrow \text { c-FLIP } \\
\text { expression level }\end{array}$ & $\begin{array}{l}\text { Abou El Naga et } \\
\text { al. (2013) [85] }\end{array}$ \\
\hline & & & $\begin{array}{l}\text { In vitro } \\
\text { BEL-7402 and QGY-7703 } \\
40 \mu \mathrm{M}\end{array}$ & $\begin{array}{l}\downarrow \text { STAT3 signaling pathway. } \downarrow \\
\text { Bcl-xL, } \downarrow \text { c-Myc, } \downarrow \text { VEGF, and } \downarrow \\
\text { cyclin D1 }\end{array}$ & $\begin{array}{l}\text { Wang et al. } \\
\text { (2013) [86] }\end{array}$ \\
\hline & & & $\begin{array}{l}\text { In vitro } \\
\text { HCCLM6 cells } \\
\text { dose-dependent }(10-100 \mu \mathrm{g} / \mathrm{mL})\end{array}$ & $\begin{array}{l}\uparrow \text { apoptosis, } \downarrow \text { metastasis via } \downarrow \\
\text { MMP- } 2, \downarrow \text { MMP-9 } \\
\downarrow \text { HSP } \beta 1 \text {, and } \downarrow \text { chaperonin }\end{array}$ & $\begin{array}{l}\text { Zhang et al. } \\
\text { (2013) [18] }\end{array}$ \\
\hline & & & $\begin{array}{l}\text { In vitro } \\
\text { HepG2 cells } \\
100 \mu \mathrm{g} / \mathrm{mL} \\
\end{array}$ & $\begin{array}{l}\downarrow \mathrm{EP}(1) \text { receptor expression and } \downarrow \\
\text { PGE(2) production }\end{array}$ & $\begin{array}{c}\text { Jin et al. (2012) } \\
\text { [87] }\end{array}$ \\
\hline & & & $\begin{array}{l}\text { In vitro } \\
\text { HepG2 cells } \\
100 \mu \mathrm{M}\end{array}$ & $\begin{array}{l}\uparrow \text { apoptosis and } \downarrow \mathrm{Bcl}-2 \text { and } \uparrow \\
\text { miR-16 }\end{array}$ & $\begin{array}{l}\text { Tsang and Kwok } \\
\text { (2010) [34] }\end{array}$ \\
\hline & & & $\begin{array}{l}\text { In vitro } \\
\mathrm{HEP}-3 \mathrm{~B} \\
10 \mu \mathrm{M}\end{array}$ & $\begin{array}{l}\downarrow \text { thrombin-induced HCC } \\
\text { invasion and } \\
\text { p42/p44-MAPKinase activation }\end{array}$ & $\begin{array}{l}\text { Kaufmann et al. } \\
\text { (2009) [15] }\end{array}$ \\
\hline & & & $\begin{array}{l}\text { In vitro } \\
\text { p53 positive Hep G2 and p53 negative Hep } \\
3 \mathrm{~B} \text { cells } \\
80 \mu \mathrm{M}\end{array}$ & $\begin{array}{l}\uparrow \mathrm{AMPK}, \downarrow \text { mTOR, } \downarrow 4 \mathrm{E}-\mathrm{BP} 1, \downarrow \\
\text { mRNA translation, } \downarrow \text { FASN, and } \\
\downarrow \text { ACC }\end{array}$ & $\begin{array}{l}\text { Huang et al. } \\
(2009) \text { [88] }\end{array}$ \\
\hline & & & $\begin{array}{l}\text { In vitro/in vivo } \\
\text { HuH7 cells/nude mouse xenograft model } \\
25 \mu \mathrm{g} / \mathrm{mL} \text {, time dependent; } 0-100 \mu \mathrm{g} / \mathrm{mL} \text {, } \\
\text { dose dependent } / 0.01 \%-0.1 \%\end{array}$ & $\begin{array}{l}\downarrow \text { VEGF2, } \downarrow \text { p-VEGFR-2; } \downarrow \text { ERK } \\
\text { and Akt, and } \downarrow \text { Bcl-x(L) }\end{array}$ & $\begin{array}{l}\text { Shirakami et al. } \\
\text { (2009) [89] }\end{array}$ \\
\hline & & & $\begin{array}{l}\text { In vitro } \\
\text { BEL7404/ADM cells, BEL7402/5-FU cells } \\
\text { IC10 } 24.76 \mathrm{mg} / \mathrm{L}, 20.60 \mathrm{mg} / \mathrm{L} \\
\text { IC50 } 3.85 \mathrm{mg} / \mathrm{L}, 2833.62 \mu \mathrm{mol} / \mathrm{L}\end{array}$ & $\begin{array}{l}\downarrow \text { MDR in HCC, } \downarrow \text { MDR } 1, \downarrow \text { LRP } \\
\text { expression, and } \uparrow \text { cyclin G1 } \\
\text { expression }\end{array}$ & $\begin{array}{l}\text { Tang et al. } \\
(2008)[90]\end{array}$ \\
\hline & & & $\begin{array}{l}\text { In vitro } \\
\text { HepG2, SMMC-7721 } \\
100-400 \mu \mathrm{g} / \mathrm{mL}\end{array}$ & $\begin{array}{l}\downarrow \text { COX-2, } \downarrow \text { Bcl- } 2 \text { (over } \\
200 \mu \mathrm{g} / \mathrm{mL} \text { ) } \\
\uparrow \text { caspase- } 9 \text { and } \uparrow \text { caspase- } 3(100 \\
\text { and } 200 \mu \mathrm{g} / \mathrm{mL} \text { for } 12 \mathrm{~h} \text { ) }\end{array}$ & $\begin{array}{l}\text { Chen et al. } \\
(2008)[16]\end{array}$ \\
\hline & & & $\begin{array}{l}\text { In vitro } \\
\text { HepG2 } \\
20 \mu \mathrm{g} / \mathrm{mL}\end{array}$ & $\begin{array}{l}\downarrow \text { IGF/IGF-1 receptor dependent } \\
\text { signaling pathway by } \uparrow \text { apoptosis, } \\
\downarrow \text { p-IGF-1R protein, } \downarrow \text { p-ERK, } \downarrow \\
\text { p-Akt, } \downarrow \text { p-Stat- } 3 \text {, and } \downarrow \\
\text { p-GSK-3 } \beta \text { proteins; } \downarrow \text { IGF-1, } \\
\text { IGF- } 2 \text {, and } \uparrow \text { IGFBP-3 }\end{array}$ & $\begin{array}{l}\text { Shimizu et al. } \\
\text { (2008) [32] }\end{array}$ \\
\hline
\end{tabular}


TABLE 1: Continued.

\begin{tabular}{|c|c|c|c|c|}
\hline Subfamily Flavonoids & Typical origin & $\begin{array}{l}\text { In vitro/in vivo } \\
\text { Cell lines/modes } \\
\text { Effective dose }\end{array}$ & Effects and related mechanisms & $\begin{array}{l}\text { Author (year) } \\
\text { References }\end{array}$ \\
\hline & & $\begin{array}{l}\text { In vitro } \\
\text { SK-Hep- } 1 \text { cells } \\
20 \mu \mathrm{g} / \mathrm{mL}\end{array}$ & $\begin{array}{l}\downarrow \text { tumor invasion and migration } \\
\text { via } \downarrow \text { MMP-9 and MMP-2 }\end{array}$ & $\begin{array}{l}\text { Sang et al. } \\
(2007)[91]\end{array}$ \\
\hline & & $\begin{array}{l}\text { In vitro/in vivo } \\
\mathrm{HLE} \text { cells/BALB/c nude mice } \\
0-100 \mu \mathrm{g} / \mathrm{mL} / 0.8,2.5 \text { and } 7.5 \mathrm{mg} / \mathrm{mL}\end{array}$ & $\begin{array}{l}\uparrow \text { apoptosis in HLE cells via } \downarrow \\
\text { Bcl- } 2 \alpha, \downarrow \text { Bcl-xl } \downarrow \text { NF- } \kappa \text { B; } \uparrow \\
\text { TRAIL-induced apoptosis }\end{array}$ & $\begin{array}{l}\text { Nishikawa et al. } \\
\text { (2006) [75] }\end{array}$ \\
\hline & & $\begin{array}{l}\text { In vitro } \\
\mathrm{HepG} 2 \\
50 \mu \mathrm{mol} / \mathrm{L}\end{array}$ & $\begin{array}{l}\downarrow \text { hypoxia induced HIF-1 protein; } \\
\downarrow \text { VEGF; } \downarrow \text { PI3/Akt/mTOR } \\
\text { pathways, and } \downarrow \text { ERK } 1 / 2 \\
\text { signaling pathways }\end{array}$ & $\begin{array}{l}\text { Zhang et al. } \\
(2006)[92]\end{array}$ \\
\hline
\end{tabular}

$\uparrow$ : Intensify; $\downarrow$ : attenuate; N/A: none available; EGCG: (-)-epi-gallocatechin-3-gallate; SD rats: Sprague Dawley rats; DEN: diethylnitrosamine; MMP: matrix metalloproteinase; TIMP: metallopeptidase inhibitor 1; FGF: fibroblast growth factor; EGFR: epidermal growth factor receptor; CYP: cytochrome; PKC $\alpha$ : protein kinase C-alpha; EMT: epithelial-mesenchymal transition; I $\kappa$ B- $\beta$ : I-kappa- $\beta$; PI3: phosphatidylinositol 3-kinase; PTEN: phosphatase and tensin homolog; NFAT1: nuclear factor of activated T cells 1; DR: death receptor; TRAIL: tumor necrosis factor-related apoptosis inducing ligand; c-FLIP: cellular FLICE inhibitory protein; STAT3: signal transducer and activator of transcription 3; VEGF: vascular endothelial growth factor; EP(1): prostaglandin E receptor 1; MAPK: p38-beta mitogen-activated protein kinase; AMPK: AMP-activated protein kinase; mTOR: mammalian target of rapamycin; 4E-BP1: eukaryotic initiation factor 4E-binding protein-1; FASN: fatty acid synthase; ACC: acetyl-CoA carboxylase; ERK: extracellular signal regulated kinases; MDR: multidrug resistance; LRP: lung resistance protein; IGF: insulin-like growth factor; GSK-3 $\beta$ : glycogen synthase kinase-3 $\beta$; HIF-1: hypoxia-inducible factors; IGFBP-3: insulin-like growth factor binding protein-3; ER: endoplasmic reticulum; UPR: unfolded protein response; JNK: c-Jun N-terminal kinases; MTP: mitochondrial transmembrane potential; CAM-DR: cell adhesion mediated drug resistance; MDR: multidrug resistance; MAC: mitochondrial apoptosis-induced channel; AIF: apoptosis-inducing factor; 5-FU: 5-fluororuracil; PARP: poly ADP-ribose polymerase; AP-1: activator protein 1; ATO: arsenic trioxide; FAK: focal adhesion kinase; CDK: cyclin-dependent kinases; GRP: glucose-regulated protein; CHOP: C/EBP-homologous protein; ROS: reactive oxygen species; DOX: doxorubicin; HSP: heat shock proteins; PKC- $\alpha$ : protein kinase C-alpha; $\alpha$-FP: alpha-fetoprotein; CPK: checkpoint kinase 1; SOD: superoxide dismutase; HIF: hypoxiainducible factor; GSH: glutathione; T-AOC: total antioxidant capability; AC-H: acetylation of histone $\mathrm{H}$.

2.1. (-)-Epi-gallocatechin-3-gallate. Tea is the most widely consumed beverage worldwide; furthermore, green tea is sold on a large scale, in part, due to its chemotherapeutic value $[62,63]$. A typical cup of green tea generally contains $100-$ $150 \mathrm{mg}$ of catechins, including 50\% (-)-epigallocatechin-3gallate (EGCG), 15\% EGC, 15\% (-)-epicatechin-3-gallate, and $8 \%(-)$-epicatechin [60]. More detailed, in vivo mouse studies have established that EGCG can function as a strong chemopreventive agent against cancer development and progression [115]. Numerous studies have shown that the green tea extract derived from the dried fresh leaves of the plant Camellia sinensis and one of its major constituents, EGCG, possess obvious antioxidant [116], antiproliferative [117], antiangiogenic [118], antimetastatic [119], and proapoptotic [120, 121] activities, as well as the ability to perturb the cell cycle [122] in various in vitro and in vivo tumor models. EGCG has immense potential as a therapeutic agent for the treatment and/or prevention of cancer due to its low cost and high bioavailability [123].

The anticancer role of EGCG has been investigated epidemiologically, in in vitro and in vivo models, as well as in clinical trials [124]. As the most potent antitumor component in green tea, EGCG has been shown to inhibit several critical signal transduction pathways [125], particularly the specific receptor tyrosine kinases and their downstream signaling pathways, in several cancer cell lines [126-128]. It has also been shown to have antiangiogenesis $[129,130]$ and antimetastatic properties [131, 132].

Particularly the investigation of critical signal transduction pathways in HCC has been carried out recently. The insulin-like growth factor (IGF) signaling axis has been shown to play a critical role in the development and progression of various tumors. The type 1 insulin-like growth factor receptor (IGF-1R) belongs to the tyrosine kinase receptor family. When activated by its ligands, it protects several cell types from a variety of apoptotic injuries. The main signaling pathway for IGF-1R-mediated protection from apoptosis has been previously elucidated and rests on the activation of phosphatidylinositol 3-kinase, Akt/protein kinase B, and the phosphorylation and inactivation of $\mathrm{BAD}$, a member of the Bcl-2 family of proteins [133]. A recent study of the effects of EGCG on hepatoma cell lines has shown that EGCG inhibits the activation of IGF/IGF-1R-dependent signaling pathways by inducing apoptosis and causing a decrease in p-IGF-1R protein and its downstream signaling molecules, including the p-ERK, p-Akt, p-Stat3, and p-GSK-3 $\beta$ proteins [32]. The phosphatidylinositol $3^{\prime}$-kinase (PI3K)/AKT pathway has been reported to play an important role in cancer proliferation and migration. Previous studies indicate the role of the PI3K/AKT pathway in the development and progression of HCC cells, mainly reflected in the mechanism of liver cancer cell proliferation, differentiation, and apoptosis. EGCG affects both upstream and downstream targets of AKT [33]. Signal transducer and activator of transcription 3 (STAT3) is one of the seven members of the Stat protein family, which mediates the actions of many cytokines and growth factors. STAT3 serves as an oncogene that promotes cell survival, proliferation, and motility. STAT3 shows constitutive activity in many different types of cancers, including breast, prostate, head and neck, lung, colon, liver, and pancreatic cancers, as well as large granular lymphocytic leukemia and multiple myeloma [134]. A study has revealed that EGCG can inhibit 
TABLE 2: Baicalein in HCC with possible mechanisms discussed in this paper.

\begin{tabular}{|c|c|c|c|c|c|}
\hline Subfamily & Flavonoids & Typical origin & $\begin{array}{l}\text { In vitro/in vivo } \\
\text { Cell lines/modes } \\
\text { Effective dose }\end{array}$ & Effects and related mechanisms & $\begin{array}{l}\text { Author (year) } \\
\text { References }\end{array}$ \\
\hline \multirow[t]{8}{*}{ Flavones } & Baicalein & $\begin{array}{l}\text { Scutellaria baicalensis } \\
\text { (Scutellaria radix) roots } \\
\quad \text { (Sho-Saiko-To) }\end{array}$ & $\begin{array}{l}\text { In vitro } \\
\text { HepG2 cells } \\
0,12.5,25 \text { and } 50 \mu \mathrm{M}\end{array}$ & $\begin{array}{l}\uparrow \text { protective autophagy, } \downarrow \\
\text { AKT/mTOR pathways } \\
\downarrow \text { p-AKT, p-ULK1, and p-4EBP1 }\end{array}$ & $\begin{array}{l}\text { Wang et al. } \\
(2015)[20]\end{array}$ \\
\hline & & & $\begin{array}{l}\text { In vitro } \\
\text { SMMC-7721 and Bel-7402 } \\
100 \mu \mathrm{M}\end{array}$ & $\begin{array}{l}\uparrow \text { apoptosis via ER stress, possibly } \\
\text { by } \downarrow \text { Bcl- } 2 \text { family, } \uparrow \text { intracellular } \\
\text { calcium, and } \uparrow \text { JNK } \\
\uparrow \text { protective autophagy }\end{array}$ & $\begin{array}{l}\text { Wang et al. } \\
\text { (2014) [93] }\end{array}$ \\
\hline & & & $\begin{array}{l}\text { In vitro/in vivo } \\
\mathrm{H} 22, \text { Bel- } 7404 \text {, and Hep } \\
\mathrm{G} 2 / \text { cancer inducible ICR mice } \\
0.5-100 \mu \mathrm{g} / \mathrm{mL} / 50 \text { and } 100 \mathrm{mg} / \mathrm{kg}\end{array}$ & $\begin{array}{l}\uparrow \mathrm{G} 0 / \mathrm{G} 1 \text { cell cycle arrest, } \downarrow \text { cancer } \\
\text { cell proliferation, } \downarrow \text { AKT } \\
\downarrow \beta \text {-catenin, and } \downarrow \text { cyclin D1 }\end{array}$ & $\begin{array}{l}\text { Zheng et al. } \\
\text { (2014) [21] }\end{array}$ \\
\hline & & & $\begin{array}{l}\text { In vitro/in vivo } \\
\text { MHCC } 97 \mathrm{H} \text { cells/nude mouse } \\
\text { model LCI-D20 } \\
0,10,20 \text {, and } \\
30 \mu \mathrm{M} / 10 \mathrm{mg} / \mathrm{kg} / \text { day }\end{array}$ & $\begin{array}{l}\downarrow \text { tumor cell invasion, } \downarrow \text { metastasis } \\
\text { by } \downarrow \text { cell motility } \\
\downarrow \text { migration via } \downarrow \text { ERK pathway, } \downarrow \\
\text { MMP- } 2, \downarrow \text { MMP-9, } \downarrow \text { u-PA } \\
\text { expression, } \uparrow \text { TIMP- } 1 \text {, and } \uparrow \\
\text { TIMP- } 2 \text { expression }\end{array}$ & $\begin{array}{l}\text { Chen et al. } \\
\text { (2013) [37] }\end{array}$ \\
\hline & & & $\begin{array}{l}\text { In vitro/in vivo } \\
\text { HepG } 2 / \mathrm{HCC} \text { xenografts in mice } \\
40-120 \mu \mathrm{M} / \mathrm{N} / \mathrm{A}\end{array}$ & $\begin{array}{l}\uparrow \text { apoptosis, } \downarrow \text { MEK1, } \downarrow \text { ERK1/2, } \downarrow \\
\text { Bad, } \downarrow \text { MTP, } \uparrow \text { caspase-9, and } \uparrow \\
\text { caspase-3 }\end{array}$ & $\begin{array}{l}\text { Liang et al. } \\
(2012)[76]\end{array}$ \\
\hline & & & $\begin{array}{l}\text { In vitro/in vivo } \\
\mathrm{HA} 22 \mathrm{~T} / \mathrm{VGH} \text { and SK-Hep1 } \\
\text { cells/BALB c-nu mice } \\
10 \mu \mathrm{M} / 5,10 \text {, and } 20 \mathrm{mg} / \mathrm{kg} / \text { day }\end{array}$ & $\begin{array}{l}\downarrow \text { adhesion, invasion, migration, } \\
\text { and proliferation } \\
\downarrow \text { metastasis; } \downarrow \text { MMP-2, } \downarrow \text { MMP-9, } \\
\text { and } \downarrow \text { uPA, } \\
\downarrow \text { p50 and } 65 \text { nuclear } \\
\text { translocation, and } \downarrow \text { pI } \kappa \text { B- } \beta \\
\downarrow \text { pPKC } \alpha \text { and p38 MAPK }\end{array}$ & $\begin{array}{l}\text { Chiu et al. (2011) } \\
\text { [94] }\end{array}$ \\
\hline & & & $\begin{array}{l}\text { In vitro } \\
\text { Hep J5 cells } \\
10-100 \mu \mathrm{M}\end{array}$ & $\begin{array}{l}\uparrow \mathrm{G} 2 / \mathrm{M} \text { arrest and } \uparrow \text { apoptosis } \\
\text { (ER-dependent) } \\
\uparrow \text { cytochrome c release, } \uparrow \text { caspase- } 9 \\
\text { and caspase- } 3, \uparrow \text { Bax/Bcl- } 2 \text { ratio, } \uparrow \\
\text { AIF, and Endo G release from } \\
\text { mitochondria }\end{array}$ & $\begin{array}{l}\text { Kuo et al. (2009) } \\
\text { [95] }\end{array}$ \\
\hline & & & $\begin{array}{l}\text { In vitro } \\
\text { Hep G2 cells } \\
25,50 \text {, and } 100 \mu \mathrm{M}\end{array}$ & $\begin{array}{l}\uparrow \mathrm{G} 2 / \mathrm{M} \text { population in Hep G2 cells } \\
\uparrow \text { apoptosis and } \downarrow \text { proliferation }\end{array}$ & $\begin{array}{l}\text { Chang et al. } \\
(2002)[96]\end{array}$ \\
\hline
\end{tabular}

For abbreviations see footer of Table 1.

HCC via the STAT3 pathway [86]. Recent studies indicate that AMPK activation strongly suppresses cell proliferation in nonmalignant cells, as well as in tumor cells. AMPK mediates these effects through multiple mechanisms, including regulation of the cell cycle, apoptosis, and autophagy, as well as the inhibition of protein synthesis and de novo fatty acid synthesis. Altered levels of AMPK have been linked with many human diseases, including cancer, and the modulation of AMPK has emerged as an important target for the treatment of obesity, diabetes, and cancer [135]. The AMPK signaling system contains some tumor suppressing genes, including L $\kappa \mathrm{B} 1, \mathrm{TSC} 1, \mathrm{TSC} 2$, and p53, and suppresses tumor growth by inhibiting the activity of various protooncogenes, such as PI3K, Akt, and ERK. The AMPK pathway is linked to tumor growth and proliferation through the inhibition of the mammalian target of rapamycin (mTOR) pathway via activation of the TSC2-TSC1 complex. EGCG has also been shown to be involved in the activation of AMPK via the suppression of downstream substrates, such as mTOR and eukaryotic initiation factor 4E-binding protein-1 (4E$\mathrm{BP} 1$ ), as well as a general decrease in mRNA translation, which resulted in the apoptosis of p53-negative Hep 3B cells [88]. Proteinase-activated receptors (PARs) comprise a subfamily of G-protein-coupled receptors. PAR1, PAR3, and PAR4 are activated mainly by thrombin. Recently, PAR1 and PAR4 have been found to coordinately regulate HCC cell migration, suggesting a role for these two PAR subtypes in HCC progression [136]. Previous reports have shown that EGCG inhibits the thrombin-PAR1/PAR4-p42/p44 mitogenactivated protein kinase (MAPK) invasive signaling axis in HCC cells [15]. The apoptosis pathways have been ranked as the most common gate for anticarcinogenesis, which 
TABLE 3: Oroxylin A in HCC with possible mechanisms discussed in this paper.

\begin{tabular}{|c|c|c|c|c|c|}
\hline Subfamily & Flavonoids & Typical origin & $\begin{array}{l}\text { In vitro/in vivo } \\
\text { Cell lines/modes } \\
\text { Effective dose }\end{array}$ & Effects and related mechanisms & $\begin{array}{l}\text { Author (year) } \\
\text { References }\end{array}$ \\
\hline \multirow[t]{6}{*}{ Flavones } & Oroxylin A & $\begin{array}{l}\text { Scutellaria } \\
\text { baicalensis } \\
\text { Georgi }\end{array}$ & $\begin{array}{l}\text { In vitro } \\
\text { HepG2 } \\
25-100 \mu \mathrm{M}\end{array}$ & $\begin{array}{l}\uparrow \mathrm{H}_{2} \mathrm{O}_{2} \text {-triggered overactivation of } \\
\text { the UPR pathway and } \\
\downarrow \text { AKT signaling }\end{array}$ & $\begin{array}{l}\text { Xu et al. (2012) } \\
{[23]}\end{array}$ \\
\hline & & & $\begin{array}{l}\text { In vitro/in vivo } \\
\text { HepG2 cells/BALB/c nude mice } \\
80 \mu \mathrm{M} / 40 \mathrm{mg} / \mathrm{kg} ; 80 \mathrm{mg} / \mathrm{kg}\end{array}$ & $\begin{array}{l}\uparrow \text { autophagy-mediated antitumor } \\
\text { activity } \\
\downarrow \text { PI3K-PTEN-Akt-mTOR signaling } \\
\text { pathway }\end{array}$ & $\begin{array}{c}\text { Zou et al. (2012) } \\
{[24]}\end{array}$ \\
\hline & & & $\begin{array}{l}\text { In vitro } \\
\text { HepG2 cells } \\
50,100 \text { and } 200 \mu \mathrm{M}\end{array}$ & $\downarrow$ CAM-DR, $\downarrow$ integrin $\beta 1$ & $\begin{array}{c}\text { Zhu et al. (2012) } \\
\text { [80] }\end{array}$ \\
\hline & & & $\begin{array}{l}\text { In vitro/in vivo } \\
\mathrm{HepG} 2 \text { cells/transplanted } \mathrm{H} 22 \\
\text { mice } \\
50 \mu \mathrm{M} / 1,000 \mathrm{mg}(\mathrm{kg} / \text { day })\end{array}$ & $\begin{array}{l}\uparrow \text { sensitivity of HepG } 2 \text { cells to } 5 \text {-FU } \\
\text { by } \uparrow \text { P } 53 \text { and cleaved PARP; } \downarrow \\
\text { COX- } 2, \downarrow \text { Bcl- } 2 \text {, and } \downarrow \\
\text { pro-caspase- } 3\end{array}$ & $\begin{array}{l}\text { Zhao et al. } \\
\text { (2010) [79] }\end{array}$ \\
\hline & & & $\begin{array}{l}\text { In vitro } \\
\text { HepG2 cells } \\
50,100 \text {, and } 200 \mu \mathrm{M}\end{array}$ & $\begin{array}{l}\uparrow \text { apoptosis by MAC-related } \\
\text { mitochondrial pathway }\end{array}$ & $\begin{array}{l}\text { Liu et al. (2009) } \\
\text { [40] }\end{array}$ \\
\hline & & & $\begin{array}{l}\text { In vitro } \\
\text { HepG2 } \\
50,100 \text {, and } 150 \mu \mathrm{M}\end{array}$ & $\begin{array}{l}\uparrow \text { apoptotic and } \mathrm{G}(2) / \mathrm{M} \text { phase } \\
\text { arrest cells } \\
\uparrow \text { programmed cell death via } \downarrow \text { Bcl-2 } \\
\text { protein, } \downarrow \text { pro-caspase-3 protein, } \\
\text { and } \uparrow \text { Bax protein }\end{array}$ & $\begin{array}{l}\text { Hu et al. (2006) } \\
\text { [97] }\end{array}$ \\
\hline
\end{tabular}

For abbreviations see footer of Table 1.

can be subclassified as the mitochondria-mediated intrinsic pathway, the death receptor-induced extrinsic pathway, and apoptotic signaling evoked by endoplasmic reticulum (ER) stress. Caspases are intracellular cysteine protease responsible for and associated with these three apoptosis pathways. The intrinsic apoptotic pathway is a mitochondria-involved signaling cascade in which caspase- 9 is the predominant initiator caspase. The cytochrome $c$ released from the mitochondria to the cytosol binds to Apaf-1, resulting in proteolytic processing and activation of caspase-9. Active caspase- 9 then activates caspase-3, initiating a cascade of additional caspase activations that culminates in apoptosis. Caspase activation is regulated by various cellular proteins, including inhibitorof-apoptosis, cellular FLICE-inhibitory protein (c-FLIP), and $\mathrm{Bcl}-2$ family proteins. The $\mathrm{Bcl}-2$ family of proteins can be divided into two groups: suppressors of apoptosis (e.g., Bcl-2, $\mathrm{Bcl}-\mathrm{XL}$, and Mcl-1) and activators of apoptosis (e.g., Bax, Bok, Hrk, and Bad). Some physiological proapoptotic molecules (e.g., Bax) are downregulated or inactivated in HCC, while many cancer cells resist apoptosis through upregulation of the Bcl-2 gene [137]. EGCG was shown to delay HCC cell growth through the inhibition of Bcl-2 family members $[34,75]$ or by inducing apoptosis in HCC cells via downregulation of COX-2 and Bcl- 2 and consequently activating caspase- 9 and caspase-3 [16]. In contrast to the intrinsic pathway, the extrinsic apoptotic pathway is mediated by death receptors, such as the receptors for Fas ligand (Fas-L) and tumor necrosis factor- (TNF-) related apoptosis-inducing ligand (TRAIL). Caspase- 8 is a major initiator caspase in this pathway. Similar to the Fas/Fas-L system, TRAIL transduces apoptosis in a number of cancers. TRAIL, a member of the TNF family, is considered to be a promising anticancer agent due to its ability to induce apoptosis in a variety of tumor cell types. Cellular sensitivity to TRAIL depends on the expression of cell-membrane TRAIL receptors and caspase- 8 . Caspase- 8 is activated in response to TRAIL and is released into the cytoplasm, where it initiates a protease cascade that activates effector caspases such as caspase- 3 and caspase-7. TRAIL is known to trigger apoptosis through binding to death receptors DR4 and DR5. The subsequent interaction of DR4 or DR5 with the adaptor molecule FADD, via their respective death domains leads to recruitment and activation of caspase8. Finally, caspase- 8 activates the executioner caspases (e.g., caspase- 3 and caspase-7), leading to apoptotic cell death. HCC is insensitive towards TRAIL-mediated apoptosis, suggesting that the presence of mediators can inhibit the TRAIL cell-death-inducing pathway in HCC. The combination of TRAIL with chemotherapeutic agents or anticancer cytokines may be a novel strategy for the treatment of HCC [138]. EGCG has been found to be capable of sensitizing cells toward TRAIL-induced apoptosis by upregulating of caspase3 activity and DR4 and DR5 expression, downregulating of $\mathrm{Bcl}-2$ expression, and decreasing the c-FLIP expression level [85].

In a study by Shan et al., a low concentration of acrylamide was able to significantly induce CYP2E1 expression in Hep G2 cells. EGCG was proposed to effectively reduce acrylamide-induced proliferation, as well as the expression 
TABLE 4: Genistein in HCC with possible mechanisms discussed in this paper.

\begin{tabular}{|c|c|c|c|c|c|}
\hline Subfamily & Flavonoids & Typical origin & $\begin{array}{l}\text { In vitro/in vivo } \\
\text { Cell lines/modes } \\
\text { Effective dose }\end{array}$ & Effects and related mechanisms & $\begin{array}{l}\text { Author (year) } \\
\text { References }\end{array}$ \\
\hline \multirow[t]{11}{*}{ Isoflavone } & Genistein & $\begin{array}{l}\text { Dyer's broom } \\
\text { (Genista } \\
\text { tinctoria) }\end{array}$ & $\begin{array}{l}\text { In vitro } \\
\text { HepG2 cells } \\
1.0 \text { and } 10 \mu \mathrm{M}\end{array}$ & $\begin{array}{l}\text { Regulation of MDR proteins, } \uparrow \\
\text { P-gp, and } \uparrow \text { MRP2 protein; } \\
\text { nutrient-drug interactions, } \uparrow \\
\text { chemoresistance to sorafenib }\end{array}$ & $\begin{array}{l}\text { Rigalli et al. } \\
\text { (2015) [31] }\end{array}$ \\
\hline & & & $\begin{array}{l}\text { In vitro/in vivo } \\
\text { HepG2 cells/nude mice } \\
3,6 \text {, and } 9 \mu \mathrm{M} / 50 \mathrm{mg} / \mathrm{kg} \mathrm{BW}\end{array}$ & $\begin{array}{l}\uparrow \text { E-cadherin, } \uparrow \alpha \text {-catenin, } \downarrow \\
N \text {-cadherin, and Vimentin } \\
\downarrow \text { intrahepatic metastasis by } \downarrow \text { EMT, } \\
\text { which was correlated with } \downarrow \text { NFAT1 }\end{array}$ & $\begin{array}{l}\text { Dai et al. (2015) } \\
\text { [22] }\end{array}$ \\
\hline & & & $\begin{array}{l}\text { In vitro } \\
\text { HepG2, Huh-7, and HA22T3 } \\
\text { dose dependent } \geq 20 \mu \mathrm{M}\end{array}$ & $\begin{array}{l}\downarrow \text { NF- } \kappa \mathrm{B}, \downarrow \text { AP- } 1 \downarrow \text { MAPK, I } \kappa \mathrm{B} \text {, and } \\
\downarrow \text { PI3K/Akt, } \downarrow \text { MMP-9, and } \downarrow \text { EGFR }\end{array}$ & $\begin{array}{l}\text { Wang et al. } \\
(2014)[98]\end{array}$ \\
\hline & & & $\begin{array}{l}\text { In vitro/in vivo } \\
\text { HCCLM3 cells/nude mice } \\
\text { bearing human HCC xenografts } \\
40 \mu \mathrm{mol} / \mathrm{L} / 2 \mathrm{mg} / \mathrm{kg} / \text { day for } 4 \\
\text { weeks }\end{array}$ & $\begin{array}{l}\text { Synergistic effect with geneistin via } \\
\downarrow \text { cisplatin-induced MMP-2 } \\
\text { expression }\end{array}$ & $\begin{array}{l}\text { Chen et al. } \\
\text { (2013) [37] }\end{array}$ \\
\hline & & & $\begin{array}{l}\text { In vitro/in vivo } \\
\mathrm{HepG} 2 \text { and } \mathrm{Hep} 3 \mathrm{~B} / \mathrm{nude} \text { mice } \\
15 \mathrm{M} \text { and } 20 \mathrm{M} / 50 \mathrm{mg} / \mathrm{kg}\end{array}$ & $\begin{array}{l}\uparrow \text { ATO suppressive effect via } \downarrow \\
\text { NF- } \kappa \text { B pathway, } \downarrow \text { cyclin D } 1, \downarrow \\
\text { Bcl-xL, } \downarrow \text { Bcl- } 2, \downarrow \text { c-myc, } \downarrow \text { COX- } 2, \\
\text { and } \downarrow \text { VEGF }\end{array}$ & $\begin{array}{l}\text { Ma et al. (2011) } \\
\text { [99] }\end{array}$ \\
\hline & & & $\begin{array}{l}\text { In vitro } \\
\text { SK-Hep-1 cells } \\
0-50 \mu \mathrm{M}\end{array}$ & $\begin{array}{l}\uparrow \text { apoptosis } \uparrow \text { Fas, } \uparrow \text { FasL, and } \uparrow \text { p53; } \\
\uparrow \text { Bcl- } 2 \text {, } \uparrow \text { caspase- } 9 \text { and } \uparrow \\
\text { caspase- } 3 \text {, and } \uparrow \text { PARP cleavage }\end{array}$ & $\begin{array}{l}\text { Fang et al. } \\
(2010)[100]\end{array}$ \\
\hline & & & $\begin{array}{l}\text { In vitro/in vivo } \\
\text { HepG2, SK-Hep-1, and } \\
\text { Hep3B/HepG2 xenografts in } \\
\text { BALB/c nude mice } \\
15 \mu \mathrm{M}, 15 \mu \mathrm{M} \text {, and } \\
20 \mu \mathrm{M} / 50 \mathrm{mg} / \mathrm{kg}\end{array}$ & $\begin{array}{l}\text { Synergistic effect with ATO via } \downarrow \\
\text { Bcl- } 2 \text { expression, } \uparrow \text { Bax expression, } \\
\uparrow \text { caspase- } 9 \text { and }-3, \uparrow \text { cytochrome c, } \\
\text { and } \uparrow \text { ROS }\end{array}$ & $\begin{array}{l}\text { Jiang et al. } \\
(2010)[101]\end{array}$ \\
\hline & & & $\begin{array}{l}\text { In vitro } \\
\text { Hep3B cells } \\
12,25 \text {, and } 50 \mu \mathrm{M}\end{array}$ & $\begin{array}{l}\downarrow \text { p38MAPK and } \uparrow \\
\text { TRAIL-mediated apoptosis; } \\
\downarrow \text { ERK, } \downarrow \text { MMP, } \uparrow \text { caspase- } 3 \text {, } \\
\text { caspase- } 8 \text {, and caspase- } 9 \text { activity, } \uparrow \\
\text { PARP cleavage, and } \downarrow \text { Bcl- } 2 \text { protein }\end{array}$ & $\begin{array}{l}\text { Jin et al. (2009) } \\
\text { [39] }\end{array}$ \\
\hline & & & $\begin{array}{l}\text { In vitro } \\
\text { Hep G2 cells } \\
6.75 \mu \mathrm{M} \text { baicalein }+25,50 \text {, and } \\
100 \mu \mathrm{M} \text { silymarin }\end{array}$ & $\begin{array}{l}\uparrow \text { cells in G0/G1 phase, } \downarrow \text { S-phase } \\
\uparrow \mathrm{Rb}, \uparrow \text { p53, } \uparrow \text { p21(Cip1) and } \uparrow \\
\text { p27(Kip1), } \downarrow \text { cyclin D1, } \downarrow \text { cyclin E, } \downarrow \\
\text { CDK4, and } \downarrow \text { phospho-Rb }\end{array}$ & $\begin{array}{l}\text { Chen et al. } \\
(2008)[102]\end{array}$ \\
\hline & & & $\begin{array}{l}\text { In vitro/in vivo } \\
\mathrm{MHCC} 97-\mathrm{H} \text { cells/BALB/c nu/nu } \\
\text { mice (LCI-D20) } \\
5,10 \text {, and } 20 \mu \mathrm{g} / \mathrm{mL} / 50 \mathrm{mg} / \mathrm{kg}\end{array}$ & $\begin{array}{l}\uparrow \mathrm{G}(0) / \mathrm{G}(1) \text { cell cycle arrest, } \\
\downarrow \mathrm{S} \text { phase, and } \uparrow \text { apoptosis } \downarrow \\
\text { phosphorylation of FAK }\end{array}$ & $\begin{array}{l}\text { Gu et al. (2009) } \\
{[78]}\end{array}$ \\
\hline & & & $\begin{array}{l}\text { In vitro } \\
\text { Hep3B cells } \\
100 \mu \mathrm{M}\end{array}$ & $\begin{array}{l}\uparrow \text { ER stress and } \uparrow \text { mitochondrial } \\
\text { insult in Hep3B cells, } \uparrow \text { m-calpain, } \uparrow \\
\text { GADD153, } \uparrow \text { GRP78, and } \uparrow \\
\text { caspase- } 12 \\
\uparrow \text { caspase- } 2, \uparrow \text { ROS, } \downarrow \text { Mcl-1 }\end{array}$ & $\begin{array}{l}\text { Yeh et al. (2007) } \\
\text { [77] }\end{array}$ \\
\hline
\end{tabular}

For abbreviations see footer of Table 1.

of CYP2E1, epidermal growth factor receptor (EGFR), cyclin $\mathrm{D} 1$, and nuclear factor kappa-light-chain-enhancer of activated $B$ cells $(\mathrm{NF}-\kappa \mathrm{B})$ proteins [17]. The ER is also a major organelle for oxygen and nutrient sensing as cells adapt to their microenvironment. Stresses that disrupt ER function lead to the accumulation of unfolded proteins in the ER, a condition known as ER stress. To prevent cells from the harmful effects of ER stress, a sophisticated signal pathway called the unfolded protein response (UPR) is triggered to attenuate protein translation, degrade misfolded protein, and induce 
TABLE 5: Galangin in HCC with possible mechanisms discussed in this paper.

\begin{tabular}{|c|c|c|c|c|c|}
\hline Subfamily & Flavonoids & Typical origin & $\begin{array}{l}\text { In vitro/in vivo } \\
\text { Cell lines/modes } \\
\text { Effective dose }\end{array}$ & Effects and related mechanisms & $\begin{array}{l}\text { Author (year) } \\
\text { References }\end{array}$ \\
\hline \multirow[t]{4}{*}{ Flavonols } & Galangin & $\begin{array}{l}\text { Alpinia } \\
\text { officinarum }\end{array}$ & $\begin{array}{l}\text { In vitro } \\
\text { HepG2 cell } \\
74 \text {, and } 148 \mu \mathrm{M}\end{array}$ & $\begin{array}{l}\uparrow \text { autophagy via } \uparrow \text { TGF- } \beta \\
\text { receptor/Smad pathway }\end{array}$ & $\begin{array}{l}\text { Wang et al. } \\
(2014) \text { [25] }\end{array}$ \\
\hline & & & $\begin{array}{l}\text { In vitro } \\
\text { HepG2, Hep3B, and PLC/PRF/5 cells } \\
134.0,87.3 \text {, and } 79.8 \mu \mathrm{M} \text { for } 24 \mathrm{~h}\end{array}$ & $\begin{array}{l}\uparrow \text { MAPKs involved in ER stress with } \\
\uparrow \text { GRP94, } \uparrow \text { GRP78 and } \uparrow \text { CHOP, } \\
\text { and } \uparrow \text { free cytosolic } \mathrm{Ca}^{2+} \\
\text { concentration }\end{array}$ & $\begin{array}{l}\text { Su et al. }(2013) \\
{[103]}\end{array}$ \\
\hline & & & $\begin{array}{l}\text { In vitro } \\
\text { HepG2 cells } \\
\text { Autophagy }(130 \mu \mathrm{mol} / \mathrm{L}) \text { and apoptosis } \\
(370 \mu \mathrm{mol} / \mathrm{L})\end{array}$ & $\begin{array}{l}\uparrow \text { apoptosis, } \uparrow \text { autophagy through a } \\
\text { p53-dependent pathway }\end{array}$ & $\begin{array}{l}\text { Wen et al. (2012) } \\
\text { [81] }\end{array}$ \\
\hline & & & $\begin{array}{l}\text { In vitro } \\
\text { HepG2, Hep3B, and PLC/PRF/5 } \\
46.25-370.0 \mu \mathrm{mol} / \mathrm{L}\end{array}$ & $\begin{array}{l}\uparrow \text { apoptosis through a } \\
\text { mitochondrial pathway } \uparrow \text { AIF, } \uparrow \\
\text { cytochrome c }\end{array}$ & $\begin{array}{l}\text { Zhang et al. } \\
(2010)[104]\end{array}$ \\
\hline
\end{tabular}

For abbreviations see footer of Table 1.

molecular chaperone expression. A series of ER-localized proteins and enzymes, such as PKR-like ER kinase, inositolrequiring enzyme 1, and activating transcription factor 6 (ATF6), are activated by the UPR. CHOP, a downstream protein of ATF4 and ATF6, is the best characterized factor in the transition of ER stress to apoptosis. During UPR, the accumulated misfolded/unfolded proteins are subjected to protein degradation by the ubiquitin-proteasome pathway. However, if cells are unable to restore homeostasis because of prolonged ER stress, apoptosis is triggered in the damaged cells [139].

Normally, the UPR is considered a cell survival mechanism when ER stress is activated in many cell types. However, if ER stress persists, the proliferation of cells is inhibited. Because of the dual-cell survival/cell death roles of ER stress, this pathway remains a complicated target for cancer therapy. Therefore, a careful analysis of circumstances is required to determine whether to inhibit or promote ER stress for successful anticancer therapy. Emerging evidence suggests that the ER also regulates apoptosis both by sensitizing mitochondria to a variety of extrinsic and intrinsic death stimuli and by initiating cell death signals of its own. In addition to propagating death-inducing stress signals itself, the ER also contributes in a fundamental way to Fas-mediated apoptosis and to p53-dependent pathways resulting from DNA damage and oncogene expression. Mobilization of ER calcium stores can initiate the activation of cytoplasmic death pathways, as well as sensitize mitochondria to direct proapoptotic stimuli. Additionally, the existence of Bcl-2regulated initiator procaspase activation complexes at the ER membrane has also been described [139]. Experiments carried out in microsomes and hepatoma cells revealed that EGCG can reduce the reactivation of carcinogens by inhibiting glucuronide transport in the ER and triggering ER stress and apoptosis in hepatoma cells by inhibition of glucosidase II [140]. The transforming growth factor$\beta$ (TGF- $\beta$ ) signaling pathway is believed to contribute to carcinoma development by increasing cell invasiveness and metastasis and inducing the epithelial-to-mesenchymal transition (EMT). TGF- $\beta$ signaling occurs following the binding of the TGF- $\beta$ ligand to TGF- $\beta$ receptor I (TGF- $\beta$ RI), which heterodimerizes with TGF- $\beta$ RII. This heterodimer complex phosphorylates the intracellular proteins Smad 2 and 3 , activating a downstream cascade that produces a nuclear transduction protein. TGF- $\beta$ is an important pathophysiological pathway in the liver associated with fibrogenesis. It promotes extracellular matrix (ECM) deposition in hepatic stellate cells after viral or metabolic injury. The final outcome of this process is decreased liver function, which often presents clinically as liver cirrhosis. This loss of liver function commonly precedes the onset of HCC in Western countries [141]. EGCG was found to downregulate the mRNA level of Smad7 and to mediate apoptosis in HepG2 cells via the TGF/Smad signaling pathway [35]. PGE2 is a prostaglandin that is abundant in HCC. Studies have established the important role of the PGE2 synthesis pathway as a potential target for the treatment and/or prevention of HCC $[142,143]$. PGE2 exerts its biological activities primarily via G-proteincoupled prostaglandin receptors (four different receptors designated EP1, EP2, EP3, and EP4), which belong to the highly conserved superfamily of 7-transmembrane-spanning proteins [144]. Among these four EP receptors, studies have shown EP1 to be the most important in tumor development. EP1, through activation of EGFR/c-Met signaling, plays an important role in tumor cell invasion. A selective EP1 agonist increased the phosphorylation of EGFR, which suggests that it may enhance the invasion of tumor cells [145]. EGCG has also been shown to suppress EP1 receptor expression and PGE2 production [87]. EGCG can also influence HCC angiogenesis and metastasis via different mechanisms. EGCG was demonstrated to exert its antiangiogenesis ability through activation of vascular endothelial growth factor receptor(VEGFR-) 2 and related downstream signaling molecules, including ERK and Akt [89]. EGCG also causes a drastic 
TABLE 6: Quercetin in HCC with possible mechanisms discussed in this paper.

\begin{tabular}{|c|c|c|c|c|c|}
\hline Subfamily & Flavonoids & Typical origin & $\begin{array}{l}\text { In vitro/in vivo } \\
\text { Cell lines/modes } \\
\text { Effective dose }\end{array}$ & Effects and related mechanisms & $\begin{array}{l}\text { Author (year) } \\
\text { References }\end{array}$ \\
\hline \multirow[t]{11}{*}{ Flavonols } & Quercetin & $\begin{array}{l}\text { Fruits, vegetables, } \\
\text { leaves, and grains }\end{array}$ & $\begin{array}{l}\text { In vitro } \\
\text { HepG2 cells } \\
10,20 \text {, and } 40 \mu \mathrm{M}\end{array}$ & $\begin{array}{l}\text { Apoptotic cell death by regulating cell } \\
\text { cycle and } \downarrow \text { antiapoptotic proteins } \\
\text { (Sp1 and Sp1 regulatory protein) }\end{array}$ & $\begin{array}{l}\text { Lee et al. (2015) } \\
\qquad[27]\end{array}$ \\
\hline & & $\begin{array}{l}\text { Berries, grapes, } \\
\text { potatoes, tomatoes, } \\
\text { and onions } \\
\text { Beverages (tea, wine, } \\
\text { and bear) }\end{array}$ & $\begin{array}{l}\text { In vitro } \\
\text { HepG } 2 \text { cell line } \\
12.5-100 \mu \mathrm{M}\end{array}$ & $\begin{array}{l}\uparrow \mathrm{G} 2 / \mathrm{M} \text { phase arrest accompanied by } \\
\text { an } \uparrow \text { apoptotic cell death apoptosis } \\
\text { via } \uparrow \mathrm{p} 53, \uparrow \mathrm{p} 21, \downarrow \text { Cyclin D } 1, \downarrow \text { Cdk } 2 \text {, } \\
\text { Cdk7 levels, and } \uparrow \text { ROS }\end{array}$ & $\begin{array}{l}\text { Li et al. (2014) } \\
\qquad[28]\end{array}$ \\
\hline & & & $\begin{array}{l}\text { In vitro } \\
\text { HepG2 cells } \\
50 \mu \mathrm{M}\end{array}$ & $\begin{array}{l}\uparrow \text { p16-mediated cell cycle arrest and } \uparrow \\
\text { apoptosis }\end{array}$ & $\begin{array}{l}\text { Zhao et al. } \\
\text { (2014) [105] }\end{array}$ \\
\hline & & & $\begin{array}{l}\text { In vivo } \\
\text { DEN induced liver cancer rats } \\
10 \mathrm{mg} / \mathrm{kg}\end{array}$ & $\begin{array}{l}\uparrow \text { apoptosis, } \uparrow \text { caspase } 9 \uparrow \text { caspase } 3 \text {, } \\
\text { and } \uparrow \text { PARP } \\
\text { (the intrinsic mitochondrial } \\
\text { pathway) } \\
\downarrow \text { lipid peroxidation } \\
\downarrow N F \kappa B\end{array}$ & $\begin{array}{l}\text { Vásquez- } \\
\text { Garzón et al. } \\
\text { (2013) [106] }\end{array}$ \\
\hline & & & $\begin{array}{l}\text { In vitro/in vivo } \\
\text { Hepatoma SMMC7721 cells and } \\
\text { QGY7701 cells/athymic BALB/c } \\
\text { nu/nu mice } \\
0-150 \mu \mathrm{M} / 100 \mathrm{mg} / \mathrm{kg}\end{array}$ & $\begin{array}{l}\uparrow \text { DOX-mediated apoptosis in } \\
\text { p53-dependent hepatoma cells } \\
\downarrow \text { Bcl-xl }\end{array}$ & $\begin{array}{l}\text { Wang et al. } \\
(2012)[83]\end{array}$ \\
\hline & & & $\begin{array}{l}\text { In vitro } \\
\text { HepG2 cells } \\
50 \mu \mathrm{mol} / \mathrm{L}\end{array}$ & $\downarrow$ HSPs in HepG2 cells & $\begin{array}{l}\text { Zhou et al. } \\
\text { (2011) [107] }\end{array}$ \\
\hline & & & $\begin{array}{l}\text { In vitro } \\
\text { HepG2 } \\
50 \mu \mathrm{M}\end{array}$ & $\begin{array}{l}\downarrow \mathrm{NF}-\kappa \mathrm{B} \downarrow \text { caspase- } 3, \downarrow \mathrm{p} 38 \mathrm{MAPK} \text {, } \\
\text { unbalance of Bcl-2 proapoptotic and } \\
\text { antiapoptotic proteins, } \uparrow \text { JNK, and } \uparrow \\
\text { AP-1 regulation of } \\
\text { survival/proliferation (AKT, ERK) }\end{array}$ & $\begin{array}{l}\text { Granado- } \\
\text { Serrano et al. } \\
(2010)[108]\end{array}$ \\
\hline & & & $\begin{array}{l}\text { In vitro } \\
\mathrm{HA} 22 \mathrm{~T}, \mathrm{VGH} \text {, and HepG2 cells } \\
40 \mu \mathrm{M}\end{array}$ & $\begin{array}{l}\uparrow \text { oxidative stress, } \uparrow \text { ROS } \\
\uparrow \text { apoptotic action of } \\
\text { 2-methoxyestradiol }\end{array}$ & $\begin{array}{l}\text { Chang et al. } \\
(2009)[109]\end{array}$ \\
\hline & & & $\begin{array}{l}\text { In vitro } \\
\text { HepG } 2 \text { and SK-Hep1 } \\
20,100 \text {, and } 200 \mu \mathrm{M}\end{array}$ & $\begin{array}{l}\uparrow \text { TRAIL-induced apoptosis via } \uparrow \\
\text { Sp1-mediated DR5 and } \downarrow \text { c-FLIPS }\end{array}$ & $\begin{array}{l}\text { Kim et al. } \\
(2008)[110]\end{array}$ \\
\hline & & & $\begin{array}{l}\text { In vitro } \\
\text { HepG2 } \\
50 \mu \mathrm{M}\end{array}$ & $\begin{array}{l}\text { Tight regulation of } \\
\text { survival/proliferation pathways via } \downarrow \\
\mathrm{PI} 3 / \mathrm{AKT}, \downarrow \text { ERK, } \downarrow \text { PKC- } \alpha \text {, } \uparrow \mathrm{JNK}, \\
\text { and } \uparrow \mathrm{PKC} \text {-delta }\end{array}$ & $\begin{array}{l}\text { Granado- } \\
\text { Serrano et al. } \\
(2008)[82]\end{array}$ \\
\hline & & & $\begin{array}{l}\text { In vitro } \\
\text { HepG2 cells } \\
10-50 \mu \mathrm{mol} / \mathrm{L}\end{array}$ & $\begin{array}{l}\uparrow \text { caspase- } 3, \uparrow \text { caspase }-9, \downarrow \\
\text { Bcl-xL/Bcl-xS, } \\
\downarrow \text { major survival signals, } \downarrow \text { Akt, and } \downarrow \\
\text { ERK }\end{array}$ & $\begin{array}{l}\text { Granado- } \\
\text { Serrano et al. } \\
(2006)[42]\end{array}$ \\
\hline
\end{tabular}

For abbreviations see footer of Table 1.

decrease in VEGF expression at both the mRNA and protein levels and inhibits the expression of serum-induced hypoxiainducible factor 1 (HIF-1) alpha protein by interfering with the phosphatidylinositol 3-kinase/Akt/mTOR signaling pathways [92]. EGCG was found to exert its antimetastatic properties via inhibition of MMP-2 and MMP-9 activities $[18,19,91,146]$. An additional study pointed out that EGCG inhibits vascular invasion via reduced expression of MMP-9, syndecan-1, and FGF-2 [36]. EGCG was also been found to exert its anticancer ability by reversing multidrug resistance [90].

2.2. Baicalein. Baicalein is one of the key flavonoids isolated from the roots of Scutellaria baicalensis or Scutellariae radix (Huangqin in Chinese), a famous Chinese medicinal herb. It possesses various biological activities, including 
TABLE 7: Silibinin in HCC with possible mechanisms discussed in this paper.

\begin{tabular}{|c|c|c|c|c|c|}
\hline Subfamily & Flavonoids & Typical origin & $\begin{array}{l}\text { In vitro/in vivo } \\
\text { Cell lines/modes } \\
\text { Effective dose }\end{array}$ & Effects and related mechanisms & $\begin{array}{c}\text { Author (year) } \\
\text { References }\end{array}$ \\
\hline \multirow[t]{7}{*}{ Flavonolignans } & S Silibinin & $\begin{array}{l}\text { Extract of the milk } \\
\text { thistle seeds } \\
\text { Milk thistle plant } \\
\text { (Silybum } \\
\text { marianum) }\end{array}$ & $\begin{array}{l}\text { In vitro } \\
\text { SNU761 cell line, Huh-BAT cell } \\
\text { line } \\
100 \mu \mathrm{M}\end{array}$ & $\begin{array}{l}\downarrow \text { EGFR-dependent Akt signaling } \\
\uparrow \text { growth-inhibiting effects of both } \\
\text { gefitinib and sorafenib }\end{array}$ & $\begin{array}{c}\text { Gu et al. (2015) } \\
{[30]}\end{array}$ \\
\hline & & & $\begin{array}{l}\text { In vitro/in vivo } \\
\text { HepG2 cells/male athymic nude } \\
\text { mice } \\
5,10 \text {, or } 20 \mu \mathrm{M} \text { ( } \downarrow \text { tumor cell } \\
\text { adhesion, migration); } \\
50,100 \text {, and } 200 \mu \mathrm{M} / 200 \text {, } \\
400 \mathrm{mg} / \mathrm{kg} / \text { day ( } 5 \text { days/week) }\end{array}$ & $\begin{array}{l}\downarrow \text { tumor cell adhesion, migration, } \downarrow \\
\text { GSH, } \downarrow \text { T-AOC } \uparrow \text { apoptotic index, } \uparrow \\
\text { caspase- } 3 \text {, and } \uparrow \text { ROS } \\
\downarrow \text { notch signaling via } \downarrow \text { Notch1 } \\
\text { intracellular domain (NICD), } \downarrow \\
\text { RBP-J } \kappa \text {, and } \downarrow \text { Hes } 1 \text { proteins, } \\
\uparrow \text { Bax, } \downarrow \text { Bcl } 2, \downarrow \text { survivin, and } \downarrow \\
\text { cyclin D } 1\end{array}$ & $\begin{array}{l}\text { Zhang et al. } \\
\text { (2013) [29] }\end{array}$ \\
\hline & & & $\begin{array}{l}\text { In vivo } \\
\mathrm{HuH7} \text { xenografts } \\
80 \text { and } 160 \mathrm{mg} / \mathrm{kg} / \text { day }\end{array}$ & $\begin{array}{l}\downarrow \text { Ki- } 67 \text { and } \downarrow \alpha \text {-FP production, } \downarrow \\
\text { NF- } \kappa \text { B content, } \downarrow \text { polo-like kinase } 1 \text {, } \\
\downarrow \text { Rb phosphorylation, and } \downarrow \\
\text { E2F1/DP1 complex } \\
\uparrow \text { p } 27 / C D K 4 \text { complex and CPK } 1 \\
\text { expression } \\
\text { mediated by } \downarrow \text { G1-S transition of the } \\
\text { cell cycle } \\
\downarrow \text { survivin phosphorylation } \\
\downarrow \text { cell proliferation } \\
\downarrow \text { p-ERK, } \uparrow \text { PTEN/PI(3)K/Akt, and } \\
\uparrow \text { ERK pathways } \\
\uparrow \text { AC-H3 and AC-H4 expression } \\
\text { and } \uparrow \text { SOD- } 1\end{array}$ & $\begin{array}{l}\text { Cui et al. (2009) } \\
\text { [111] }\end{array}$ \\
\hline & & & $\begin{array}{l}\text { In vitro } \\
\text { Hep3B } \\
500 \mu \mathrm{M}\end{array}$ & $\begin{array}{l}\downarrow \text { cell proliferation } \\
\downarrow \text { HIF- } 1 \alpha \text { and } \\
\downarrow \text { mTOR/p70S6K/4E-BP1 signalling } \\
\text { pathway }\end{array}$ & $\begin{array}{c}\text { García-Maceira } \\
\text { et al. }(2009) \\
{[112]}\end{array}$ \\
\hline & & & $\begin{array}{l}\text { In vitro } \\
\text { HepG-2 } \\
25,50 \text { and } 75 \mu \mathrm{M}\end{array}$ & $\begin{array}{l}\downarrow \text { cell proliferation, } \downarrow \text { MMP } 2 \\
\text { enzymatic activity, } \downarrow \text { NO } \\
\downarrow \text { ERK } 1 / 2, \uparrow \text { RKIP, Spred-1, and } \\
\text { Spred- } 2 \\
\downarrow \text { cell growth and proliferation via } \downarrow \\
\text { Hecl, and MMP-2 }\end{array}$ & $\begin{array}{l}\text { Momeny et al. } \\
(2008) \text { [43] }\end{array}$ \\
\hline & & & $\begin{array}{l}\text { In vitro } \\
\text { HuH7 cells } \\
240 \mu \mathrm{mol} / \mathrm{L}\end{array}$ & $\begin{array}{l}\uparrow \mathrm{p} 21 / \mathrm{CDK} 4 \text { and } \mathrm{p} 27 / \mathrm{CDK} 4 \\
\text { complexes, } \\
\downarrow \text { Rb-phosphorylation } \downarrow \text { E2F1/DP1 } \\
\text { complex } \\
\downarrow \text { survivin } \uparrow \text { caspase-3 and } \uparrow \\
\text { caspase-9 } \\
\text { antiangiogenic effects via } \downarrow \text { MMP2 } \\
\text { and } \downarrow \text { CD } 34 \\
\uparrow \text { PTEN and } \downarrow \text { p-Akt production } \\
\uparrow \mathrm{AC}-\mathrm{H} 3 \text { and AC-H4 }\end{array}$ & $\begin{array}{c}\text { Lah et al. (2007) } \\
{[113]}\end{array}$ \\
\hline & & & $\begin{array}{l}\text { In vitro } \\
\text { HepG2 and Hep3B cells } \\
100-300 \mu \mathrm{mol} / \mathrm{L}\end{array}$ & $\begin{array}{l}\uparrow \mathrm{G} 1 \text { arrest in HepG2 and } \uparrow \mathrm{G} 1 \text { and } \\
\mathrm{G} 2-\mathrm{M} \text { arrests in Hep3B cells } \\
\uparrow \mathrm{Kip} 1 / \mathrm{p} 27, \downarrow \text { cyclin } \mathrm{D} 1, \downarrow \text { cyclin D3, } \\
\downarrow \text { cyclin E, } \downarrow \text { CDK- } 2 \text {, and } \downarrow \text { CDK4 } \\
\downarrow \text { G2-M regulators, } \downarrow \text { CDK } 2, \downarrow \\
\text { CDK4, and } \downarrow \text { CDC } 2 \text { kinase activity }\end{array}$ & $\begin{array}{l}\text { Varghese et al. } \\
\text { (2005) [114] }\end{array}$ \\
\hline
\end{tabular}

For abbreviations see footer of Table 1. 
anti-inflammatory [147], antioxidative [148], neuroprotective [149], cardiovascular protective [150], and antihyperglycemic [151] effects. It has broadly been used in remedies for hepatitis [152], cirrhosis [153], jaundice, and HCC in traditional Chinese, Japanese, and Korean medicine [96]. Accumulated evidence has demonstrated the anticancer potential of baicalein in plenty of cancer cell lines, including esophageal carcinoma [154], HCC [96], bladder cancer [155], prostate cancer [69], colon cancer [156], and pancreatic cancer [157]. The mechanisms underlying these baicalein-mediated anticancer effects include arrest of cancer cell cycle progression, induction of apoptosis, and blockage of invasion. Recent studies have shed light on the potential molecular pathways involved in the activity of baicalein against HCC $[21,37,96]$. Chang et al. had shown that baicalein induces cell cycle arrest and apoptosis in HCC cells. Their later study indicated that apoptosis induced by baicalein may be attributed to mitochondrial dysfunction [38]. Baicalein was found to trigger apoptotic episodes via the mitochondria-dependent caspase pathway, through activation of caspase- 9 and caspase-3; increased $\mathrm{Bax} / \mathrm{Bcl}-2$ ratio and altered mitochondrial membrane potential with subsequent cytochrome $c$ release; and the caspaseindependent pathway via apoptosis-inducing factor (AIF) and endonuclease $G$ (Endo $G$ ) release from mitochondria $[20,95,158]$. Autophagy is a dynamic degradation process for delivering dysfunctional cellular components or foreign invaders to lysosome to be digested by lysosomal hydrolase. Autophagy may inhibit tumor formation by degrading damaged organelles or proteins. After tumor formation, however, the tumor can use autophagy as a survival mechanism to counter against hypoxia, starvation, and an acid environment. Natural products as autophagy regulators have been reported to be prosurvival or prodeath [158]. A study by Wang et al. demonstrated that baicalein can trigger autophagy and inhibit the protein kinase $\mathrm{B} / \mathrm{mTOR}$ pathway in a HepG2 cell line [20]. The c-Jun NH2-terminal kinase (JNK) signal transduction pathway induces defense mechanisms that protect organisms against acute oxidative and xenobiotic insults. This pathway has also been repeatedly linked to the molecular events involved in the regulation of autophagy [159]. Besides protective autophagy, baicalein also induced apoptosis via ER stress by downregulating prosurvival Bcl-2 family members, increasing intracellular calcium, and activating JNK [93]. The antitumor effect of baicalein may also be attributed to the deactivation of the PI3K/Akt pathway. A recent study from Zheng et al. demonstrated that baicalein inhibits Akt and promotes the degradation of $\beta$-catenin and cyclin D1 independent of GSK-3 $\beta$. This result was also confirmed in an animal model [21]. Liang et al. recently revealed that MEK/ERK plays an important role both in vitro and in vivo. Baicalein inhibits MEK1 and subsequently reduces the activation of ERK1/2, leading to apoptosis and tumor growth arrest in mice with liver cancer [76]. Suppression of this pathway may also lead to attenuated cell migration and invasion by blocking multiple proteases that degrade the ECM [37]. NF$\kappa \mathrm{B}$ is a ubiquitous transcription factor consisting of p50, p65, and I-kappa-B(I $\kappa \mathrm{B})-\alpha$, which resides in the cytoplasm and is activated in response to various inflammatory stimuli, environmental pollutants, prooxidants, carcinogens, stress, and growth factors. Growing evidence shows that NF- $\kappa \mathrm{B}$ is one of the major culprits involved in the development of drug resistance in cancer, including HCC $[160,161]$. Baicalein has been proposed to be involved in the NF- $\kappa$ B pathway via decreasing p50 and p65 nuclear translocation and decreasing the phosphorylation of I $\kappa \mathrm{B}-\beta$ in hepatoma cells [94].

Metastasis is one of the leading causes of cancer-related death among patients with HCC. Cancer invasion and metastasis are complicated multistep processes involving numerous effector molecules. Degradation of the ECM in blood or lymph vessels is an essential step in cancer invasion and metastasis because loss of the ECM allows cancer cells to invade the blood or lymphatic system and spread to other tissues and organs. Matrix metalloproteinases (MMPs), a family of zinc-dependent endopeptidases that degrade almost all ECM components, play important roles in cancer invasion and metastasis.

Among the MMPs, MMP-2 and MMP-9 have been implicated in HCC invasion and metastasis. Upregulation of MMPs would facilitate degradation of the ECM, thus enhancing the metastatic ability of cancer cells [162]. In the plasminogen activation system, urokinase-type plasminogen activator (u-PA) activity may be the most sensitive factor reflecting HCC invasion; it is frequently used as a strong predictor of HCC recurrence [163]. Baicalein has been found to modulate antimetastatic effects and anti-invasion capabilities via inhibition of MMP-2 and MMP-9 activities [37]. The study demonstrated that treatment of HCC cell lines with baicalein decreases the expression of MMP-2, MMP-9, and u$\mathrm{PA}$, as well as tissue inhibitor of metalloproteinase-1 (TIMP-1) and TIMP-2, in a dose-dependent fashion [37, 94].

2.3. Genistein. Genistein (5,7,4' -trihydroxyisoflavone), a soybean-derived isoflavone, has been identified as a potential cause for the low incidence of certain types of tumors, including lung cancer [164], breast cancer [165], gastric cancer [166], colon cancer [167], HCC [168], and prostate cancers [169]. Genistein can exert its chemopreventive activities in each stage of multistep carcinogenesis through inhibiting tumor cell proliferation, inducing tumor cell differentiation, and triggering cell cycle arrest and apoptosis in some cell types $[170,171]$. Genistein may affect HCC progression as a result of its effects on cell cycle progression and apoptosis [172]. Fang et al. demonstrated that genistein not only activated the mitochondrial apoptosis pathway through the activation of caspase- 9 and caspase- 3 followed by cleavage of poly (ADPribose) polymerase (PARP) but also activated the Fas pathway by increasing the expression of Fas, FasL, and p53 proteins [100]. Genistein has also been demonstrated to increase the production of intracellular reactive oxygen species (ROS) and has been found to exert a synergistic effect with arsenic trioxide (ATO) via the mitochondrial apoptosis pathway [101]. Notably, it has been suggested that ER stress and the associated activation of NF- $\kappa \mathrm{B}, \mathrm{ATF}-6$, and MAPKs may contribute to hepatocarcinogenesis. A study by Yeh et al. demonstrated that genistein induces the activation of several ER stressrelevant regulators, including m-calpain, GADD153, GRP78, and caspase-12 [77]. Activation of caspase-2, manifested as mitochondrial insult by genistein, also triggers apoptotic cell 
death [77]. Genistein has been reported to suppress ATK and the NF- $\kappa$ B pathway through different pathways $[98,99]$. Combination of ATO with genistein presents a promising therapeutic approach for the treatment of HCC. Its efficacy is mediated via the suppressive effect of genistein on both proper and ATO-induced Akt activation and on the activity of NF- $\kappa \mathrm{B}$. The latter correlates with the suppression of NF$\kappa \mathrm{B}$-regulated gene products, including cyclin $\mathrm{D} 1, \mathrm{Bcl}-\mathrm{xL}$, Bcl-2, c-myc, COX-2, and VEGF [99]. The generic MAPK signaling pathway is shared by four distinct cascades, including the extracellular signal-related kinases (ERK1/2), the Jun aminoterminal kinases (JNK1/2/3), p38-MAPK, and ERK5. The MAPK/ERK pathway is reported to be associated with the cell proliferation, differentiation, migration, senescence, and apoptosis [173]. Jin et al. also reported that genistein enhances TRAIL-induced apoptosis through inhibition of p38 MAPK signaling in human HCC Hep3B cells [39]. Genistein possesses anti-invasive and antimetastatic activities against TPA-mediated metastasis via downregulation of MMP-9 and EGFR and subsequent suppression of NF- $\kappa$ B and AP-1 transcription factors through the inhibition of MAPK, $\mathrm{I} \kappa \mathrm{B}$, and $\mathrm{PI} 3 \mathrm{~K} / \mathrm{Akt}$ signaling pathways [98].

The EMT is of paramount relevance for embryonic development and adult wound healing. The EMT contributes to the formation and differentiation of tissues and organs. The conversion of epithelial cells to mesenchymal cells is critical for embryonic development and is implicated in phenotypic changes such as the loss of cell-cell adhesion, changes in cell polarity, and the acquisition of migratory properties. During the past decade, the EMT has been increasingly recognized to occur during the progression of various carcinomas, such as HCC. Hepatocellular EMT is a crucial event in HCC progression that causes an increase in hepatocyte malignancies associated with tumor cell invasion and metastasis [174]. In humans, the nuclear factor of activated $\mathrm{T}$ cells (NFAT) family comprises five subtypes, referred to as NFAT1-5. They are ubiquitously expressed in various mammalian tissues. The NFAT pathway axis is a vertebrate-specific signaling pathway important for different cellular functions. Several recent studies have demonstrated the important roles for NFATs in regulating phenotypes related with malignancy and neoplastic progression. NFATs are upregulated in human solid cancers and hematological tumors and appear to have functions in cancer cell-autonomous actions such as invasion, migration, and differentiation, as well as the proliferation of cells in tumors and its microenvironment. Dai et al. reported that treatment with genistein suppressed the EMT induced by TGF- $\beta$, which may also contribute to reduced NFAT1, and inhibited the intrahepatic metastasis [22]. Gu et al. reported that genistein had antimetastatic potential, with a proposed mechanism involving cell cycle progression and apoptosis in MHCC97-H cells both in vitro and in vivo [78].

2.4. Oroxylin A. Oroxylin A is a naturally occurring monoflavonoid extracted from the root of S. baicalensis Georgi or $S$. radix. Oroxylin A, which manifests as a major bioactive flavone and exists in the aglycone form. It is known to exert anti-inflammatory [175], antiviral [176], antiangiogenesis [55], antipruritic [177], and neuroprotective properties
[178] and to restore liver function [179]. The anticancer effects of oroxylin A have also been studied in several cell lines, such as those derived from lung cancer [180], breast cancer [181], gastric cancer [182], HCC [24], colon cancer [183], cervical cancer [184], and leukemia [185].

Investigations of its activity against HCC have also been carried out recently. MDM2 was proposed to be related to the high invasiveness of HCC through inactivation of the tumor-suppressor function of the p53 gene [186]. Oroxylin A could serve as a novel candidate for cancer therapy through its stabilization of p53 expression, as well as its induction of apoptosis at the posttranslational level via the downregulation of MDM2 expression and its interference with MDM2modulated, proteasome-related p53 degradation [187]. The mitochondrial apoptotic pathway has been investigated as the mechanism by which oroxylin A exerts its chemopreventive activity in HCC. Oroxylin A was found to effectively induce programmed cell death by suppressing expression of $\mathrm{Bcl}-2$ protein and pro-caspase- 3 protein and also by dramatically increasing in the number of cells undergoing apoptosis and $\mathrm{G}(2) / \mathrm{M}$ phase arrest [97]. Oroxylin A was also noted for its synergistic effect when combined with 5-fluorouracil (5FU) in human HCC HepG2 cells in vitro and in transplanted murine hepatoma 22 (H22) tumors in vivo. Oroxylin A enhanced 5-FU-induced apoptosis in HepG2 cells by elevating the expression of apoptosis-inducing proteins p53 and cleaved PARP and by decreasing expression of apoptoticinhibitory proteins $\mathrm{COX}-2, \mathrm{Bcl}-2$, and pro-caspase-3 [79]. PTP and MAC are mitochondrial channels involved in the permeabilization of the mitochondrial outer membrane. MAC forms in the mitochondrial outer membrane early in apoptosis and provides a direct pathway for the release of cytochrome $c$ from the intermembrane space to the cytosol. Liu et al. has suggested that opening of the MAC, but not PTP, plays a key role in oroxylin A-induced activation of the mitochondrial apoptotic pathway in HepG2 cells [40]. In addition to the mitochondrial apoptotic pathway, the unfolded protein pathway has also been reported to be an important chemoprevention mechanism for oroxylin A in HCC. $\mathrm{Xu}$ et al. proposed that an underlying molecular mechanism implicated the $\mathrm{H}_{2} \mathrm{O}_{2}$-triggered overactivation of the UPR pathway and causal inactivation of AKT signaling in the preferential cytotoxicity of oroxylin A in malignant HepG2 cells [23]. Oroxylin A also exerts its anticarcinogenic properties by targeting aberrant activation of antiapoptotic signaling pathways. Zou et al. demonstrated that oroxylin A exhibits autophagy-mediated antitumor activity in a dose- and time-dependent manner in vivo and in vitro, which is related to the suppression of the phosphatase and tensin homolog- (PTEN-) Akt-mTOR signaling pathway [24]. Integrin-mediated adhesion influences cell survival and may prevent programmed cell death. Oroxylin A can reverse the resistance caused by cell adhesion-mediated drug resistance (CAM-DR) via inhibition of integrin $\beta 1$ and its related pathway, which can dramatically increase the apoptosis induced by paclitaxel in the CAM-DR model of HepG2 cells [80]. 
2.5. Galangin. Galangin is a flavonol, a type of flavonoid present in high concentrations in medicinal plants (e.g., Alpinia officinarum), and propolis, a natural beehive product. Galangin has been shown to have antibacterial [188], antiviral [58], anti-inflammatory [56], antioxidant [189], antiallergic [190], and antiobesity [191] activities, as well as neuroprotective [192] and antineoplastic properties [193]. Galangin has potent anticancer activity against several cancer cells, such as lung cancer [194], head and neck cancer [195], breast cancer [196], HCC [25], colon cancer [197], ovarian cancer [198], leukemia [199], and melanoma cells [200]. The chemopreventive role of galangin arises through targets in different pathways. The study by Zhang et al. has shown that galangin induces apoptosis in HCCs by activating the caspase-8/t-Bid mitochondrial pathway $[41,104]$. Su et al. have proposed that galangin induces ER stress via the MAPK pathway [103]. Galangin has been found to trigger apoptosis through the autophagy pathway. TGF- $\beta$ differentially regulates autophagy in a context-specific manner. TGF- $\beta$ induces the accumulation of autophagosomes and increases the degradation rate of long-lived proteins. TGF- $\beta$ increased the mRNA expression levels of BECLIN1 (BECN1), ATG5, ATG7, and death-associated protein kinase (DAPK). Knockdown of Smad2/3, Smad4, or DAPK or inhibition of c-Jun $\mathrm{NH}(2)$-terminal kinase attenuates TGF- $\beta$-induced autophagy, indicating the involvement of both Smad and non-Smad pathways [26]. Among the two opposing TGF- $\beta$ Smad pathways in endothelial cell systems (Smad1/5/8 and Smad2/3), Smad2 was found to be the major transcriptional regulator of autophagy that targets BECN1 gene expression. Smad2, but not Smad3, acts as a repressor upstream of the BECN1 promoter region [201].

Wang et al. found that galangin induces autophagy via activation of the TGF- $\beta$ receptor/Smad pathway; increases TGF- $\beta$ RI, TGF- $\beta$ RII, Smad1, Smad2, Smad3, and Smad 4 levels but decreases Smad6 and Smad7 levels [25]; and also mediates autophagy via upregulation of p53 [81]. Chien et al. found that galangin inhibits the TPA-induced invasion and migration of HepG2 cells through a protein kinase C/ERK pathway, resulting in the suppression of MMP-2/MMP-9 enzymatic activity [202].

2.6. Quercetin. Quercetin is a flavonol found in abundance in onions, grapes, berries, and apples, as well as green vegetables such as broccoli and grains. It can be used as an ingredient in supplements and beverages (tea, wine, and beer) that have been shown to prevent a variety of human diseases due to their antihypertensive [203], anti-inflammatory [204], antioxidant [205], antimicrobial [206], antiviral [59], antiallergic [57], and antidiabetic [207] activities, as well as their neuroprotective [208] and anticancer effects [209]. Recent studies have found that quercetin can prevent or slow the progression of a wide variety of tumors, including lung cancer [210], gastric cancer [211], colon cancer [212], prostate cancer [213], ovarian cancer [214], and HCC [215]. Quercetin has antioxidant activity, particularly during the initiation of HCC carcinogenesis [216, 217]. Chang et al. has demonstrated that quercetin and 2-methoxyestradiol exhibit synergistic cytotoxic effects through increasing superoxide levels, annexin $\mathrm{V}$ binding, and mitochondrial disruption in HA22T/VGH and HepG2 cell lines [109]. Quercetin can also trigger cell cycle arrest. Quercetin can induce apoptotic cell death by regulating the cell cycle and suppressing antiapoptotic proteins such as Sp1 and Spl regulatory protein [27].

$\mathrm{Li}$ et al. proposed that quercetin-induced cell apoptosis involves induction of G2/M arrest, apoptosis, and cell death and is associated with increased expression of p53 and p21; decrease of cyclin D1, cyclin-dependent kinase (CDK) 2 , and CDK7 levels; and generation of reactive oxygen species in cells [28]. Quercetin also has suppressive activity against HCC cells through p16-mediated cell cycle arrest and apoptosis; its combination with cisplatin yielded synergistic inhibitory effects in suppressing cell growth and inducing apoptosis [105]. Quercetin has been known to trigger apoptosis via the mitochondrial, Akt, and ERK pathway, as observed in quercetin-treated HepG2 cells $[42,106]$. Quercetin was also found to induce a significant time-dependent inactivation of the NF- $\kappa \mathrm{B}$ pathway and a time-dependent activation of the AP-1/JNK pathway. Quercetin contributes to the regulation of survival/proliferation (AKT, ERK) and death (caspase-3, p38, and unbalance of Bcl-2 proapoptotic and antiapoptotic proteins) signals in a human hepatoma cell line (HepG2) [82, 108]. Quercetin was found to potentiate the antitumor effects of doxorubicin in liver cancer cells while protecting normal liver cells in vitro and in vivo with a proposed mechanism of p53-dependent downregulation of Bcl-xl expression [83]. cFLIP is a master antiapoptotic regulator and resistance factor that suppresses TNF- $\alpha$, Fas-L, and TRAIL-induced apoptosis, as well as apoptosis triggered by chemotherapy agents in malignant cells. c-FLIP binds to FADD and/or caspase-8 or caspase-10 and TRAIL receptor 5 (DR5) in a liganddependent and -independent fashion and forms an apoptosis inhibitory complex. This interaction, in turn, prevents formation of the death-inducing signaling complex and subsequent activation of the caspase cascade. c-FLIPs are also known to have multifunctional roles in various signaling pathways, as well as activating and/or upregulating several cytoprotective and prosurvival signaling proteins including Akt, ERK, and NF- $\kappa B$ [218]. Quercetin has been shown to recover TRAIL sensitivity in various HCC cells via upregulation of DR5 (a death receptor of TRAIL) and downregulation of c-FLIPs [110]. Heat shock proteins (HSPs) consist of a large group of proteins with negligible expressions under physiological conditions. Their expression is highly induced under stress conditions, and they are ubiquitously expressed in various tissues and organs. HSPs possess chaperone functions, facilitating the correct folding of proteins or peptides. High expression of HSPs has been demonstrated in liver cancer tissues and is correlated clinically with the severity of tumors and poor outcomes in patients with HCC [219]. Zhou et al. demonstrated that quercetin can exert a significant inhibitory effect on overall expression of HSPs in HepG2 cells, which may be a novel pathway for anticarcinogenesis [107] Sharma et al. also reported that quercetin was able to potentiate the proapoptotic action of 5-FU and carboplatin by decreasing expression of HSPs such as Hsp40 and Hsp27 [220]. 
2.7. Silibinin. Silibinin is a polyphenolic mixture of flavonolignans and the major biologically active compound extracted from the seeds of milk thistle [Silybum marianum (L), Gaertn.]. It is used around the world, including the United States, Europe, and Asia, as a traditional herbal/dietary supplement because of its strong antihepatotoxic activity against almost any kind of human liver damage/toxicity [221, 222]. The crude form of milk thistle extract, silymarin, and the major pure pharmacologically active flavonoid, silibinin, which is composed of a 1:1 mixture of Silibinins A and $\mathrm{B}$, has been shown to be immune-response modifiers in vivo [73]. It is well known that milk thistle is safe and well tolerated and that it protects the liver from drug or alcohol-related injury [74]. Thus, they have been available as over-the-counter drugs in European and Asia countries to protect the liver against external poisons. In terms of their efficacy against cancer, several studies have shown that both silymarin and silibinin are highly effective in the prevention and intervention of various cancers in both rodent and cell culture models and that their mechanisms of efficacy involve cell cycle arrest and/or apoptosis [223, 224]. The cancer sites showing silymarin and silibinin efficacy include prostate [225], skin [226], lung [227], breast [228], colon [229], HCC [29], and bladder [230].

Silibinin has been demonstrated to cause G1 arrest in HepG2 cells and both G1 and G2-M arrests in Hep3B cells. They exert their effects via Kip1/p27 but decrease cyclin D1, cyclin D3, cyclin E, CDK2, and CDK4 levels in both cell lines. Silibinin further strongly inhibits CDK2, CDK4, and CDC2 kinase activities in these HCC cells [114]. The PTEN/PI3K/Akt pathway has been associated with carcinogenesis [231]. PTEN is a negative regulator of PI3K-Akt signaling [232] and one of the most frequently inactivated genes in malignancies. Akt is a downstream protein kinase of PI3K (PTEN) and is a signal transduction protein that has been identified as one of the key elements in protecting cells from apoptosis. If unregulated, Akt promotes uncontrolled cell replication. The PI3K/Akt/mTOR pathway has been proposed to be correlated with silibinin-mediated anti-HCC effects [113]. In an in vivo study, Cui et al. also proposed that silibinin reduces HuH7 xenograft growth through the inhibition of cell proliferation, cell cycle progression, and PTEN/P-Akt and ERK signaling; induces cell apoptosis; and increases histone acetylation and SOD-1 expression [111]. Silibinin was also found to exhibit synergy with sorafenib or gefitinib, which is attributable to inhibition of EGFRdependent Akt signaling [30]. HIF-1 plays a critical role for tumor adaptation to microenvironmental hypoxia and represents an appealing chemotherapeutic target. Inhibition of mTOR, a well-known regulator of cell cycle progression and cell proliferation, causes strong G1-phase cell cycle arrest. In addition, mTOR activity can regulate apoptotic cell death in some situations [233]. A study has shown that silibinin can exert its antiproliferative effect via inhibition of HIF- $1 \alpha$ and the mTOR/p70S6 K/4E-BP1 signaling pathway in hepatoma cells [112]. Momeny et al. also demonstrated that silibinin inhibits cell growth and invasive properties in human HCC through inhibition of ERK 1/2 phosphorylation in HepG2 cells [43]. The Notch signaling pathway plays a role in cell proliferation, differentiation, tumorigenesis, and immune development. A recent report proposed a close relationship between the Notch signaling pathway and HCC pathogenesis [234]. Silibinin can trigger apoptosis via inhibition of Notch signaling, upregulation of the apoptosis pathway-related protein Bax, and downregulation of Bcl-2, survivin, and cyclin D1 [29]. Silibinin also demonstrated antiangiogenic and antimetastatic activities. The antiangiogenic effect of silibinin has also been demonstrated via the downregulation of MMP-2 and CD34 [113]. Silibinin can potentially function as a multitargeting antimetastatic agent via suppression of signals at the transcriptional level and depression of the enzymatic activity of MMP-2 [235].

\section{Conclusion}

Surgical resection and liver transplantation are the first-line treatments for HCC. However, recurrence after surgery represents a tough problem, and the prognosis of patients with recurrent disease is pessimistic. For patients with advancedstage HCC who lack the opportunity to receive curative therapy, effective treatment is even more limited. HCC is well known for its resistance to chemotherapy. Systemic chemotherapy using traditional cytotoxic drugs has little effect on patients with HCC. This leaves the small molecule targeted drug sorafenib, which targets VEGFR and is a tyrosine kinase inhibitor, as the only medication with evidence to improve the prognosis of patients with advanced-stage HCC. However, its unprecedented high cost and severe adverse effects remain obstacles for HCC treatment. The absence of an ideal therapy for HCC largely contributes to the current dilemma of HCC treatment. Flavonoids have recently been well studied for their anticancer properties and have been widely adopted due to their advantages of high efficiency, weak side effects, easy availability, and improvement of the quality of life. Several flavonoids are among the new era of evolutionary therapies that affect HCC through several pathways and target different stage of carcinogenesis. Flavonoids have recently been found to exert their anticancer properties through triggering cell cycle arrest; upregulating tumor suppressors, such as p53; interacting with various pathways, including the intrinsic (mitochondrial apoptosis pathway); and extrinsic (the death receptor pathway) apoptotic pathways, the ER-related unfolded protein pathway, autophagy, EGFR/c-Met signaling pathway, TRAIL-induced apoptosis signaling pathway, NF- $\kappa$ B-related pathway, JAK/STAT pathway, HSP-related pathway, tumor suppressor-related pathway, MAPK/JNK-mediated pathway (also known as the RasRaf-MEK-ERK pathway), JNK pathway, PI3K-PTEN-AktmTOR signaling pathway, and TGF- $\beta$ signaling pathway. They also target HCC angiogenesis and metastasis stages via multiple intracellular signals. It is still believed that a combination of drugs with different mechanisms of action may provide some benefit to overcome drug resistance and reduce side effects. Approximately $67 \%$ of all anticancer drugs originate from the bioactive compounds found in plants. Several flavonoids have been proposed to exert their synergistic effect through different mechanisms. In addition to their synergistic effects with current chemotherapeutic 
agents $[79,83,105]$ or in combination with hormonal agents [109], combinations with two flavonoids have also shown synergistic effects in treating HCC. Chen et al. have demonstrated that the combination with baicalein and silymarin in human hepatoma HepG2 cells synergistically increased the percentage of cells in G0/G1 phase and decreased those in Sphase. These effects were associated with the upregulation of $\mathrm{Rb}, \mathrm{p} 53, \mathrm{p} 21$, and p27 and the downregulation of cyclin D1, cyclin E, CDK4, and phospho-Rb, which offer mechanistic insight for their further exploitation in HCC treatment [102]. Several clinical trials have shown a dose-dependent relationship between flavonoids and their anticarcinogenic effects. However, overdose can lead to possible side effects. EGCG at high doses was reported to cause liver injury [236, 237]. Long-term toxicity also needs to be taken into account. At present, most of the anti-HCC candidates listed in this paper still lack sufficient data on their toxicity/side effects, although they have been frequently used in analyses in vitro and in vivo. Therefore, studies on their toxicity/side effects in both animals and humans should be a future direction. A randomized, double-blind, single-dose trial of baicalein conducted by $\mathrm{Li}$ et al. proved that single oral doses of $100-2,800 \mathrm{mg}$ baicalein were safe and well tolerated by healthy subjects with no toxicity to the liver or kidney [238]. In spite of their antiHCC actions in preclinical models, the low bioavailability of many potential candidates greatly limits their clinical efficacy.

Currently, silymarin, the crude form of mild thistle extract, has been successfully formulated into pills and broadly carried into the clinical fields against several hepatic diseases. A clinical study showed that short-term administration of Silibinin phosphatidylcholine (siliphos) in patients with advanced HCC resulted in detectable increases in silibinin and its metabolite, silibinin glucuronide. However, the trial failed to establish the maximum tolerated dose because the patient died soon after enrollment [239]. Silibinin has been demonstrated to have poor water solubility (approximately $40 \mu \mathrm{g} / \mathrm{mL}$ ) and oral bioavailability (approximately $0.73 \%$ ) in both rodents and humans, which restrict its clinical application [240]. In recent decades, emerging nanotechnologies provide a novel platform to solve the drug solubility problem. Polymeric micelles have the ability to encapsulate a hydrophobic drug and deliver the drug to the desired site at a concentration exceeding the intrinsic solubility of the drug. Moreover, the encapsulated drug is not only protected from contact with the contents of the gastrointestinal tract, which likely induces degradation and metabolism but also conferred with the characteristics of sustained release and direct uptake by cells. Many studies have proven that nanoparticles can transport across the intestinal membrane through paracellular or transcellular routes [241]. Duan et al. have developed mixed micelles loaded with a Silibinin-polyene phosphatidylcholine complex to improve its drug solubility and prolong its mean retention time in vivo [242]. Quercetin has also been reported to have poor water solubility and poor oral bioavailability in rats (approximately 17\%) and in humans (1\%) [243]. Mandal has demonstrated that nanoencapsulated quercetin downregulates rat hepatic MMP-13 and controls diethylnitrosamineinduced hepatocarcinogenesis [244]. At present, quercetin is considered safe only based on in vitro studies [245]. Further in vivo evaluations and clinical trials are absolutely necessary to ascertain the maximum tolerated dose and the efficacy of quercetin in adjuvant HCC therapy. Nutrientdrug interactions have been recently emphasized. Although genistein has recently been shown to exert a synergistic effect with several chemotherapeutic agents $[101,246]$, Rigalli et al. recently demonstrated that ingestion of genistein-rich soy products or dietary supplements in combination with sorafenib can result in chemoresistance via induction of multidrug resistance-associated protein 2 [31]. In contrast, $\mathrm{Gu}$ et al. have demonstrated that combination treatments with silibinin enhance the growth-inhibitory effects of both gefitinib and sorafenib, which may be attributable to the inhibition of EGFR-dependent Akt signaling [30]. Hepatocarcinogenesis usually takes a long period after exposure of the noxious stimulus, which means the duration of intake of the flavonoid is a major concern for exerting its chemopreventive effect. Thus, compliance in this group of people is also of great importance. Patient selection for those at high risk for developing HCC is also of great significance. Flavonoids may exert different chemopreventive effects, alone or in combination, against diverse etiologies of HCC. This still needs to be investigated via clinical trials. Most of the studies in most of our reviews were in vitro studies within a limited number of hepatoma cell lines. Further in vivo evaluations and clinical trials are absolutely necessary to ascertain the maximum tolerated dose and the efficacy of flavonoids in adjuvant HCC therapy. We expect that future study can translate flavonoids into clinical medicine and shed light on novel treatments for the disastrous disease known as HCC.

\section{Abbreviations}

HCC: Hepatocellular carcinoma

EGCG: (-)-Epi-gallocatechin-3-gallate

EGC: (-)-Epi-gallocatechin

IGF: Insulin-like growth factor

IGF-1R: Type 1 insulin-like growth factor receptor

PI3K: Phosphatidylinositol 3-kinase

p-: $\quad$ Phosphorylated

STAT3: Signal transducer and activator of transcription 3

AMPK: AMP-activated protein kinase

TSC: Tuberous sclerosis complex

ERK: Extracellular signal regulated kinases

mTOR: Mammalian target of rapamycin

4E-BP1: Eukaryotic initiation factor 4E-binding protein-1

PARs: Proteinase-activated receptors

MAPK: Mitogen-activated protein kinase

ER: Endoplasmic reticulum

FADD: Fas-associated death domain

FLICE: FADD-like IL- $\beta$-converting enzyme

c-FLIP: Cellular FLICE-inhibitory protein

Fas-L: Fas ligand

TNF: Tumor necrosis factor

TRAIL: TNF-related apoptosis-inducing ligand

EGFR: Epidermal growth factor receptor 


$\begin{array}{ll}\text { NF- } \kappa \text { B: } & \text { Nuclear factor } \\ & \begin{array}{l}\text { kappa-light-chain-enhancer of activated B } \\ \text { cells }\end{array} \\ \text { UPR: } & \text { Unfolded protein response } \\ \text { ATF6: } & \text { Activating transcription factor } 6 \\ \text { TGF- } \beta \text { : } & \text { Transforming growth factor- } \beta \\ \text { EMT: } & \text { Epithelial-to-mesenchymal transition } \\ \text { ECM: } & \text { Extracellular matrix } \\ \text { PGE: } & \text { Prostaglandin } \\ \text { HIF-1: } & \text { Hypoxia-inducible factor 1 } \\ \text { MMP: } & \text { Matrix metalloproteinase } \\ \text { FGF: } & \text { Fibroblast growth factor } \\ \text { AIF: } & \text { Apoptosis-inducing factor } \\ \text { Endo G: } & \text { Endonuclease G } \\ \text { JNK: } & \text { c-Jun NH2-terminal kinase } \\ \text { GSK-3 } \beta: & \text { Glycogen synthase kinase-3 } \beta \\ \text { ERK: } & \text { Extracellular signal regulated kinases } \\ \text { IB: } & \text { I-Kappa-B } \\ \text { u-PA: } & \text { Urokinase-type plasminogen activator } \\ \text { TIMP: } & \text { Tissue inhibitor of metalloproteinase } \\ \text { PARP: } & \text { Poly ADP-ribose polymerase } \\ \text { ROS: } & \text { Reactive oxygen species } \\ \text { ATO: } & \text { Arsenic trioxide } \\ \text { NFAT1: } & \text { Nuclear factor of activated T cells 1 } \\ \text { MDM2: } & \text { Mouse double minute } 2 \text { homolog } \\ \text { 5-FU: } & \text { 5-Fluorouracil } \\ \text { H22: } & \text { Murine hepatoma 22 } \\ \text { PTEN: } & \text { Phosphatase and tensin homolog } \\ \text { CAM-DR: Cell adhesion mediated drug resistance } \\ \text { DAPK: } & \text { Death-associated protein kinase } \\ \text { TPA: } & \text { 12-O-Tetradecanoylphorbol-13-acetate } \\ \text { CDK: } & \text { Cyclin-dependent kinases } \\ \text { DR5: } & \text { Death receptor } 5 \\ \text { HSPs: } & \text { Heat shock proteins } \\ \text { VEGFR: } & \text { Vascular endothelial growth factor } \\ & \text { receptor. } \\ & \end{array}$

\section{Disclaimer}

The content is solely the responsibility of the authors and does not necessarily represent the official views of the National Cancer Institute or the National Institutes of Health.

\section{Conflict of Interests}

The authors have declared no conflict of interests.

\section{Authors' Contribution}

Ching-Chang Lee, Chi-chang Tsai, and Chao-Wen Hsueh, who majored in gastroenterology, participated in analyse the flavonoids impact on hepatocellular cell carcinoma. ChihChiang Wang, I-Hung Chen, Ming-Kai Tsai, and Mei-Yu Liu, who majored in nephrology, participated in paper collection and QUORUM algorithm interpretation. An-Tie Hsieh, who majored in oncology, participated in collecting the underlying mechanism of the seven flavonoids on hepatocellular carcinoma. Kuan-Jen Su and Chien-Yao Wang, who majored internal medicine, participated in figure drafting and design. Hau-Ming Wu, Shih-Chung Huang, and Yi-Chen Wang, who majored in cardiology, participated in table processing. Shu-Fang Huang, Yen-Cheng Yeh, and Ren-Jy Ben, who majored in chest and infectious disease, participated in organizing and numbering the references. Shang-Tao Chien, who majored in pathology, participated in sharing the exact laboratory experience of the flavonoids on hepatocellular carcinoma. Chin-Wen Hsu, who majored in general surgery and is the chief director of the authors' hospital, participated in supervising the paper processing. Wu-Hsien Kuo, who majored in gastroenterology and is the corresponding author, participated in providing the direction of paper writing and final paper proof.

\section{References}

[1] K. W. Burak and M. Sherman, "Hepatocellular carcinoma: consensus, controversies and future directions. A report from the Canadian Association for the Study of the Liver Hepatocellular Carcinoma Meeting," Canadian Journal of Gastroenterology \& Hepatology, vol. 29, no. 4, pp. 178-184, 2015.

[2] A. Schlachterman, W. W. Craft Jr., E. Hilgenfeldt, A. Mitra, and R. Cabrera, "Current and future treatments for hepatocellular carcinoma," World Journal of Gastroenterology, vol. 21, no. 28, pp. 8478-8491, 2015.

[3] D. M. Parkin, F. Bray, J. Ferlay, and P. Pisani, "Global cancer statistics, 2002," CA: A Cancer Journal for Clinicians, vol. 55, no. 2, pp. 74-108, 2005.

[4] P. Srivatanakul, H. Sriplung, and S. Deerasamee, "Epidemiology of liver cancer: an overview," Asian Pacific Journal of Cancer Prevention, vol. 5, no. 2, pp. 118-125, 2004.

[5] F. X. Bosch, J. Ribes, M. Díaz, and J. Ribes, "Primary liver cancer: worldwide incidence and trends," Gastroenterology, vol. 127, no. 5, supplement 1, pp. S5-S16, 2004.

[6] M. A. Feitelson, B. Sun, N. L. Satiroglu Tufan, J. Liu, J. Pan, and Z. Lian, "Genetic mechanisms of hepatocarcinogenesis," Oncogene, vol. 21, no. 16, pp. 2593-2604, 2002.

[7] H. O. El Mesallamy, N. S. Metwally, M. S. Soliman, K. A. Ahmed, and M. M. El Mesallamy, "The chemopreventive effect of Ginkgo biloba and Silybum marianum extracts on hepatocarcinogenesis in rats," Cancer Cell International, vol. 11, no. 1, article 38, 2011.

[8] S. Udali, P. Guarini, A. Ruzzenente et al., "DNA methylation and gene expression profiles show novel regulatory pathways in hepatocellular carcinoma," Clinical Epigenetics, vol. 7, article 43, 2015.

[9] H. V. Tong, C. T. Bock, and T. P. Velavan, "Genetic insights on host and hepatitis B virus in liver diseases," Mutation Research/Reviews in Mutation Research, vol. 762, pp. 65-75, 2014.

[10] M.-A. Buendia and C. Neuveut, "Hepatocellular carcinoma," Cold Spring Harbor Perspectives in Medicine, vol. 5, no. 2, Article ID a021444, 2015.

[11] M. C. Wallace, D. Preen, G. P. Jeffrey, and L. A. Adams, “The evolving epidemiology of hepatocellular carcinoma: a global perspective," Expert Review of Gastroenterology \& Hepatology, vol. 9, no. 6, pp. 765-779, 2015.

[12] S. Roayaie, I. N. Blume, S. N. Thung et al., "A system of classifying microvascular invasion to predict outcome after resection in patients with hepatocellular carcinoma," Gastroenterology, vol. 137, no. 3, pp. 850-855, 2009. 
[13] Y.-C. Shen, Z.-Z. Lin, C.-H. Hsu, C. Hsu, Y.-Y. Shao, and A.-L. Cheng, "Clinical trials in hepatocellular carcinoma: an update," Liver Cancer, vol. 2, no. 3-4, pp. 345-364, 2013.

[14] J. F. Xia, J. J. Gao, Y. Inagaki, N. Kokudo, M. Nakata, and W. Tang, "Flavonoids as potential anti-hepatocellular carcinoma agents: recent approaches using HepG2 cell line," Drug Discoveries \& Therapeutics, vol. 7, no. 1, pp. 1-8, 2013.

[15] R. Kaufmann, P. Henklein, P. Henklein, and U. Settmacher, "Green tea polyphenol epigallocatechin-3-gallate inhibits thrombin-induced hepatocellular carcinoma cell invasion and p42/p44-MAPKinase activation," Oncology Reports, vol. 21, no. 5, pp. 1261-1267, 2009.

[16] X.-L. Chen, Q. Wang, L.-Q. Cao et al., "Epigallocatechin-3gallate induces apoptosis in human hepatocellular carcinoma cells," Zhonghua Yi Xue Za Zhi, vol. 88, no. 36, pp. 2524-2528, 2008.

[17] X. Shan, Y. Li, X. Meng, P. Wang, P. Jiang, and Q. Feng, "Curcumin and (-)-epigallocatechin-3-gallate attenuate acrylamide-induced proliferation in HepG2 cells," Food and Chemical Toxicology, vol. 66, pp. 194-202, 2014.

[18] Y. Zhang, L. Owusu, W. Duan et al., "Anti-metastatic and differential effects on protein expression of epigallocatechin3-gallate in HCCLM6 hepatocellular carcinoma cells," International Journal of Molecular Medicine, vol. 32, no. 4, pp. 959-964, 2013.

[19] L. Lu, H.-M. Liu, and W.-X. Tang, "Effect of epigallocatechin3-gallate on the invasiveness of hepatocarcinoma cells in vitro," Zhonghua Gan Zang Bing Za Zhi, vol. 15, no. 11, pp. 825-827, 2007.

[20] Y.-F. Wang, T. Li, Z.-H. Tang et al., "Baicalein triggers autophagy and inhibits the protein kinase $\mathrm{B} /$ mammalian target of rapamycin pathway in hepatocellular carcinoma HepG2 cells," Phytotherapy Research, vol. 29, no. 5, pp. 674-679, 2015.

[21] Y.-H. Zheng, L.-H. Yin, T. H. M. Grahn, A.-F. Ye, Y.-R. Zhao, and Q.-Y. Zhang, "Anticancer effects of baicalein on hepatocellular carcinoma cells," Phytotherapy Research, vol. 28, no. 9, pp. 1342-1348, 2014.

[22] W. Dai, F. Wang, L. He et al., "Genistein inhibits hepatocellular carcinoma cell migration by reversing the epithelialmesenchymal transition: partial mediation by the transcription factor NFAT 1 ," Molecular Carcinogenesis, vol. 54, no. 4, pp. 301311, 2015.

[23] M. Xu, N. Lu, Z. Sun et al., "Activation of the unfolded protein response contributed to the selective cytotoxicity of oroxylin A in human hepatocellular carcinoma HepG2 cells," Toxicology Letters, vol. 212, no. 2, pp. 113-125, 2012.

[24] M. Zou, N. Lu, C. Hu et al., "Beclin 1-mediated autophagy in hepatocellular carcinoma cells: implication in anticancer efficiency of oroxylin A via inhibition of mTOR signaling," Cellular Signalling, vol. 24, no. 8, pp. 1722-1732, 2012.

[25] Y. Wang, J. Wu, B. Lin et al., "Galangin suppresses HepG2 cell proliferation by activating the TGF- $\beta$ receptor/Smad pathway," Toxicology, vol. 326, pp. 9-17, 2014.

[26] K. Kiyono, H. I. Suzuki, H. Matsuyama et al., "Autophagy is activated by TGF- $\beta$ and potentiates TGF- $\beta$-mediated growth inhibition in human hepatocellular carcinoma cells," Cancer Research, vol. 69, no. 23, pp. 8844-8852, 2009.

[27] R. H. Lee, J. H. Cho, Y.-J. Jeon et al., "Quercetin induces antiproliferative activity against human hepatocellular carcinoma (HepG2) cells by suppressing specificity protein 1 (Sp1)," Drug Development Research, vol. 76, no. 1, pp. 9-16, 2015.
[28] Y. Li, S. Duan, H. Jia, C. Bai, L. Zhang, and Z. Wang, "Flavonoids from tartary buckwheat induce $\mathrm{G}_{2} / \mathrm{M}$ cell cycle arrest and apoptosis in human hepatoma HepG2 cells," Acta Biochimica et Biophysica Sinica, vol. 46, no. 6, pp. 460-470, 2014.

[29] S. Zhang, Y. Yang, Z. Liang et al., "Silybin-mediated inhibition of notch signaling exerts antitumor activity in human hepatocellular carcinoma cells," PLoS ONE, vol. 8, no. 12, Article ID e83699, 2013

[30] H. R. Gu, S. C. Park, S. J. Choi et al., "Combined treatment with silibinin and either sorafenib or gefitinib enhances their growth-inhibiting effects in hepatocellular carcinoma cells," Clinical and Molecular Hepatology, vol. 21, no. 1, pp. 49-59, 2015.

[31] J. P. Rigalli, N. Ciriaci, A. Arias et al., "Regulation of multidrug resistance proteins by genistein in a hepatocarcinoma cell line: impact on sorafenib cytotoxicity," PLoS ONE, vol. 10, no. 3, Article ID e0119502, 2015.

[32] M. Shimizu, Y. Shirakami, H. Sakai et al., "EGCG inhibits activation of the insulin-like growth factor (IGF)/IGF-1 receptor axis in human hepatocellular carcinoma cells," Cancer letters, vol. 262, no. 1, pp. 10-18, 2008.

[33] X. Shen, Y. Zhang, Y. Feng et al., "Epigallocatechin-3-gallate inhibits cell growth, induces apoptosis and causes $S$ phase arrest in hepatocellular carcinoma by suppressing the AKT pathway," International Journal of Oncology, vol. 44, no. 3, pp. 791-796, 2014.

[34] W. P. Tsang and T. T. Kwok, "Epigallocatechin gallate upregulation of miR-16 and induction of apoptosis in human cancer cells," The Journal of Nutritional Biochemistry, vol. 21, no. 2, pp. 140-146, 2010.

[35] J.-L. Tong, F. Nie, Z.-H. Ran et al., "Epigallocatechin gallate induces apoptosis in human hepatocellular carcinoma HepG2 cells via TGF/Smad signaling pathway," Zhonghua Zhong Liu Za Zhi, vol. 31, no. 9, pp. 646-650, 2009.

[36] M. M. Darweish, A. Abbas, M. A. Ebrahim, and M. M. H. Al-Gayyar, "Chemopreventive and hepatoprotective effects of Epigallocatechin-gallate against hepatocellular carcinoma: role of heparan sulfate proteoglycans pathway," Journal of Pharmacy and Pharmacology, vol. 66, no. 7, pp. 1032-1045, 2014.

[37] K. Chen, S. Zhang, Y. Ji et al., "Baicalein inhibits the invasion and metastatic capabilities of hepatocellular carcinoma cells via down-regulation of the ERK pathway," PLoS ONE, vol. 8, no. 9, Article ID e72927, 2013.

[38] W.-H. Chang, C.-H. Chen, R.-J. Gau et al., "Effect of baicalein on apoptosis of the human Hep G2 cell line was induced by mitochondrial dysfunction," Planta Medica, vol. 68, no. 4, pp. 302-306, 2002.

[39] C.-Y. Jin, C. Park, G.-Y. Kim, S.-J. Lee, W.-J. Kim, and Y. H. Choi, "Genistein enhances TRAIL-induced apoptosis through inhibition of p38 MAPK signaling in human hepatocellular carcinoma Hep3B cells," Chemico-Biological Interactions, vol. 180, no. 2, pp. 143-150, 2009.

[40] W. Liu, R. Mu, F.-F. Nie et al., "MAC related mitochondrial pathway in oroxylin A induces apoptosis in human hepatocellular carcinoma HepG2 cells," Cancer Letters, vol. 284, no. 2, pp. 198207, 2009.

[41] H.-T. Zhang, J. Wu, M. Wen, L.-J. Su, and H. Luo, "Galangin induces apoptosis in hepatocellular carcinoma cells through the caspase 8/t-Bid mitochondrial pathway," Journal of Asian Natural Products Research, vol. 14, no. 7, pp. 626-633, 2012.

[42] A. B. Granado-Serrano, M. A. Martín, L. Bravo, L. Goya, and S. Ramos, "Quercetin induces apoptosis via caspase activation, 
regulation of Bcl-2, and inhibition of PI-3-kinase/Akt and ERK pathways in a human hepatoma cell line (HepG2)," Journal of Nutrition, vol. 136, no. 11, pp. 2715-2721, 2006.

[43] M. Momeny, M. R. Khorramizadeh, S. H. Ghaffari et al., "Effects of silibinin on cell growth and invasive properties of a human hepatocellular carcinoma cell line, HepG-2, through inhibition of extracellular signal-regulated kinase 1/2 phosphorylation," European Journal of Pharmacology, vol. 591, no. 1-3, pp. 13-20, 2008.

[44] A. S. Yu and E. B. Keeffe, "Management of hepatocellular carcinoma," Reviews in Gastroenterological Disorders, vol. 3, no. 1, pp. 8-24, 2003.

[45] G. M. Cragg, P. G. Grothaus, and D. J. Newman, "Impact of natural products on developing new anti-cancer agents," Chemical Reviews, vol. 109, no. 7, pp. 3012-3043, 2009.

[46] Y.-L. Cheng, W.-L. Chang, S.-C. Lee et al., "Acetone extract of Angelica sinensis inhibits proliferation of human cancer cells via inducing cell cycle arrest and apoptosis," Life Sciences, vol. 75, no. 13, pp. 1579-1594, 2004.

[47] J. N. Nwodo, A. Ibezim, C. V. Simoben, and F. Ntie-Kang, "Exploring cancer therapeutics with natural products from African medicinal plants, part II: alkaloids, terpenoids and flavonoids," Anti-Cancer Agents in Medicinal Chemistry, vol. 16, no. 1, pp. 108-127, 2015.

[48] A. Cassidy, G. Rogers, J. J. Peterson, J. T. Dwyer, H. Lin, and P. F. Jacques, "Higher dietary anthocyanin and flavonol intakes are associated with anti-inflammatory effects in a population of US adults," The American Journal of Clinical Nutrition, vol. 102, no. 1, pp. 172-181, 2015.

[49] M. M. de Jesús Romero-Prado, J. A. Curiel-Beltrán, M. V. Miramontes-Espino, E. G. Cardona-Muñoz, A. Rios-Arellano, and L.-B. Balam-Salazar, "Dietary flavonoids added to pharmacological antihypertensive therapy are effective in improving blood pressure," Basic and Clinical Pharmacology and Toxicology, vol. 117, no. 1, pp. 57-64, 2015.

[50] S. Chirumbolo, "Flavonoids in coronary heart disease," Thrombosis Research, vol. 135, no. 5, pp. 1040-1041, 2015.

[51] Z. Weng, A. B. Patel, S. Panagiotidou, and T. C. Theoharides, "The novel flavone tetramethoxyluteolin is a potent inhibitor of human mast cells," Journal of Allergy and Clinical Immunology, vol. 135, no. 4, pp. 1044-1052.e5, 2014.

[52] N. F. M. Fozi, M. Mazlan, A. N. Shuid, and I. N. Mohamed, "Milk thistle: a future potential anti-osteoporotic and fracture healing agent," Current Drug Targets, vol. 14, no. 14, pp. 1659-1666, 2013.

[53] W. Dong, X. Wei, F. Zhang et al., "A dual character of flavonoids in influenza A virus replication and spread through modulating cell-autonomous immunity by MAPK signaling pathways," Scientific Reports, vol. 4, article 7237, 2014.

[54] X.-F. Yang, Y.-L. Wang, and W.-R. Xu, "Reviews on antiviral activity of chemical constituents from plants," Zhongguo Zhongyao Zazhi, vol. 33, no. 1, pp. 100-104, 2008.

[55] X. Song, Y. Chen, Y. Sun et al., "Oroxylin A, a classical natural product, shows a novel inhibitory effect on angiogenesis induced by lipopolysaccharide," Pharmacological Reports, vol. 64, no. 5, pp. 1189-1199, 2012.

[56] Y. C. Jung, M. E. Kim, J. H. Yoon et al., "Anti-inflammatory effects of galangin on lipopolysaccharide-activated macrophages via ERK and NF- $\kappa \mathrm{B}$ pathway regulation," Immunopharmacology and Immunotoxicology, vol. 36, no. 6, pp. 426-432, 2014.
[57] S. Chirumbolo, "Quercetin as a potential anti-allergic drug: which perspectives?" Iranian Journal of Allergy, Asthma and Immunology, vol. 10, no. 2, pp. 139-140, 2011.

[58] S.-Y. Lyu, J.-Y. Rhim, and W.-B. Park, "Antiherpetic activities of flavonoids against herpes simplex virus type 1 (HSV-1) and type 2 (HSV-2) in vitro," Archives of Pharmacal Research, vol. 28, no. 11, pp. 1293-1301, 2005.

[59] A. E. dos Santos, R. M. Kuster, K. A. Yamamoto et al., "Quercetin and quercetin 3-O-glycosides from Bauhinia longifolia (Bong.) Steud. show anti-Mayaro virus activity," Parasites and Vectors, vol. 7, article 130, 2014.

[60] N. Horie, N. Hirabayashi, Y. Takahashi, Y. Miyauchi, H. Taguchi, and K. Takeishi, "Synergistic effect of green tea catechins on cell growth and apoptosis induction in gastric carcinoma cells," Biological and Pharmaceutical Bulletin, vol. 28, no. 4, pp. 574579, 2005.

[61] S. B. Lotito and B. Frei, "Consumption of flavonoid-rich foods and increased plasma antioxidant capacity in humans: cause, consequence, or epiphenomenon?" Free Radical Biology and Medicine, vol. 41, no. 12, pp. 1727-1746, 2006.

[62] F.-Y. Tang, N. Nguyen, and M. Meydani, "Green tea catechins inhibit VEGF-induced angiogenesis in vitro through suppression of VE-cadherin phosphorylation and inactivation of Akt molecule," International Journal of Cancer, vol. 106, no. 6, pp. 871-878, 2003.

[63] A. Kojima-Yuasa, J. J. Hua, D. O. Kennedy, and I. Matsui-Yuasa, "Green tea extract inhibits angiogenesis of human umbilical vein endothelial cells through reduction of expression of VEGF receptors," Life Sciences, vol. 73, no. 10, pp. 1299-1313, 2003.

[64] N. Khan and H. Mukhtar, "Dietary agents for prevention and treatment of lung cancer," Cancer Letters, vol. 359, no. 2, pp. 155164, 2015.

[65] A. Srinivasan, C. Thangavel, Y. Liu et al., "Quercetin regulates $\beta$-catenin signaling and reduces the migration of triple negative breast cancer," Molecular Carcinogenesis, 2015.

[66] J. L. Petrick, S. E. Steck, P. T. Bradshaw et al., "Dietary intake of flavonoids and oesophageal and gastric cancer: incidence and survival in the United States of America (USA)," British Journal of Cancer, vol. 112, no. 7, pp. 1291-1300, 2015.

[67] R. Zamora-Ros, V. Fedirko, A. Trichopoulou et al., "Dietary flavonoid, lignan and antioxidant capacity and risk of hepatocellular carcinoma in the European prospective investigation into cancer and nutrition study," International Journal of Cancer, vol. 133, no. 10, pp. 2429-2443, 2013.

[68] K. Papaj, A. Rusin, W. Szeja, and G. Grynkiewicz, "Absorption and metabolism of biologically active genistein derivatives in colon carcinoma cell line (CACO-2)," Acta Poloniae Pharmaceutica-Drug Research, vol. 71, no. 6, pp. 1037-1044, 2014.

[69] Z. Guo, X. Hu, Z. Xing et al., "Baicalein inhibits prostate cancer cell growth and metastasis via the caveolin-1/AKT/mTOR pathway," Molecular and Cellular Biochemistry, vol. 406, no. 12, pp. 111-119, 2015.

[70] Y. Wang, A. Han, E. Chen et al., "The cranberry flavonoids PAC DP-9 and quercetin aglycone induce cytotoxicity and cell cycle arrest and increase cisplatin sensitivity in ovarian cancer cells," International Journal of Oncology, vol. 46, no. 5, pp. 1924-1934, 2015.

[71] R.-H. Chou, S.-C. Hsieh, Y.-L. Yu, M.-H. Huang, Y.-C. Huang, and Y.-H. Hsieh, "Fisetin inhibits migration and invasion of human cervical cancer cells by down-regulating urokinase 
plasminogen activator expression through suppressing the p38 MAPK-dependent NF- $\kappa$ B signaling pathway," PLoS ONE, vol. 8, no. 8, Article ID e71983, 2013.

[72] K. Sak and H. Everaus, "Chemomodulating effects of flavonoids in human leukemia cells," Anti-Cancer Agents in Medicinal Chemistry, vol. 15, no. 9, pp. 1112-1126, 2015.

[73] J. Schümann, J. Prockl, A. K. Kiemer, A. M. Vollmar, R. Bang, and G. Tiegs, "Silibinin protects mice from T cell-dependent liver injury," Journal of Hepatology, vol. 39, no. 3, pp. 333-340, 2003.

[74] N. Vargas-Mendoza, E. Madrigal-Santillán, A. MoralesGonzález et al., "Hepatoprotective effect of silymarin," World Journal of Hepatology, vol. 6, no. 3, pp. 144-149, 2014.

[75] T. Nishikawa, T. Nakajima, M. Moriguchi et al., "A green tea polyphenol, epigalocatechin-3-gallate, induces apoptosis of human hepatocellular carcinoma, possibly through inhibition of Bcl-2 family proteins," Journal of Hepatology, vol. 44, no. 6 , pp. 1074-1082, 2006.

[76] R.-R. Liang, S. Zhang, J.-A. N. Qi et al., "Preferential inhibition of hepatocellular carcinoma by the flavonoid Baicalein through blocking MEK-ERK signaling," International Journal of Oncology, vol. 41, no. 3, pp. 969-978, 2012.

[77] T.-C. Yeh, P.-C. Chiang, T.-K. Li et al., "Genistein induces apoptosis in human hepatocellular carcinomas via interaction of endoplasmic reticulum stress and mitochondrial insult," Biochemical Pharmacology, vol. 73, no. 6, pp. 782-792, 2007.

[78] Y. Gu, C.-F. Zhu, Y.-L. Dai, Q. Zhong, and B. Sun, "Inhibitory effects of genistein on metastasis of human hepatocellular carcinoma," World Journal of Gastroenterology, vol. 15, no. 39, pp. 4952-4957, 2009.

[79] L. Zhao, Z. Chen, J. Wang et al., "Synergistic effect of 5fluorouracil and the flavanoid oroxylin A on HepG2 human hepatocellular carcinoma and on $\mathrm{H}_{22}$ transplanted mice," Cancer Chemotherapy and Pharmacology, vol. 65, no. 3, pp. 481-489, 2010.

[80] B. Zhu, L. Zhao, L. Zhu et al., "Oroxylin A reverses CAM-DR of HepG2 cells by suppressing Integrin $\beta 1$ and its related pathway," Toxicology and Applied Pharmacology, vol. 259, no. 3, pp. 387394, 2012.

[81] M. Wen, J. Wu, H. Luo, and H. Zhang, "Galangin induces autophagy through upregulation of p53 in HepG2 cells," Pharmacology, vol. 89, no. 5-6, pp. 247-255, 2012.

[82] A. B. Granado-Serrano, M. A. Martín, L. Bravo, L. Goya, and S. Ramos, "Time-course regulation of quercetin on cell survival/proliferation pathways in human hepatoma cells," Molecular Nutrition and Food Research, vol. 52, no. 4, pp. 457464, 2008.

[83] G. Wang, J. Zhang, L. Liu, S. Sharma, and Q. Dong, "Quercetin potentiates doxorubicin mediated antitumor effects against liver cancer through p53/Bcl-xl," PLoS ONE, vol. 7, no. 12, Article ID e51764, 2012.

[84] D. Moher, D. J. Cook, S. Eastwood, I. Olkin, D. Rennie, and D. F. Stroup, "Improving the quality of reports of meta-analyses of randomised controlled trials: the QUOROM statement. Quality of Reporting of Meta-analyses," The Lancet, vol. 354, no. 9193, pp. 1896-1900, 1999.

[85] R. N. Abou El Naga, S. S. Azab, E. El-Demerdash, S. Shaarawy, M. El-Merzabani, and E.-S. M. Ammar, "Sensitization of TRAIL-induced apoptosis in human hepatocellular carcinoma HepG2 cells by phytochemicals," Life Sciences, vol. 92, no. 10, pp. 555-561, 2013.
[86] Y. Wang, X. Ren, C. Deng et al., "Mechanism of the inhibition of the STAT3 signaling pathway by EGCG," Oncology Reports, vol. 30, no. 6, pp. 2691-2696, 2013.

[87] J. Jin, Y. Chang, W. Wei et al., "Prostanoid $\mathrm{EP}_{1}$ receptor as the target of (-)-epigallocatechin-3-gallate in suppressing hepatocellular carcinoma cells in vitro," Acta Pharmacologica Sinica, vol. 33, no. 5, pp. 701-709, 2012.

[88] C.-H. Huang, S.-J. Tsai, Y.-J. Wang, M.-H. Pan, J.-Y. Kao, and T.D. Way, "EGCG inhibits protein synthesis, lipogenesis, and cell cycle progression through activation of AMPK in p53 positive and negative human hepatoma cells," Molecular Nutrition and Food Research, vol. 53, no. 9, pp. 1156-1165, 2009.

[89] Y. Shirakami, M. Shimizu, S. Adachi et al., “(-)-Epigallocatechin gallate suppresses the growth of human hepatocellular carcinoma cells by inhibiting activation of the vascular endothelial growth factor-vascular endothelial growth factor receptor axis," Cancer Science, vol. 100, no. 10, pp. 1957-1962, 2009.

[90] H.-H. Tang, M. Zhou, and G. Liang, "Impact of epigallocatechin gallate on gene expression profiles of human hepatocellular carcinoma cell lines BEL7404/ADM and BEL7402/5-FU," $A i$ Zheng, vol. 27, no. 10, pp. 1056-1064, 2008.

[91] J. L. Sang, W. L. Ki, J. H. Haeng, Y. C. Ji, Y. K. Seo, and J. L. Hyong, "Phenolic phytochemicals derived from red pine (Pinus densiflora) inhibit the invasion and migration of SKHep-1 human hepatocellular carcinoma cells," Annals of the New York Academy of Sciences, vol. 1095, pp. 536-544, 2007.

[92] Q. Zhang, X. Tang, Q. Lu, Z. Zhang, J. Rao, and A. D. Le, “Green tea extract and (-)-epigallocatechin-3-gallate inhibit hypoxiaand serum-induced HIF- $1 \alpha$ protein accumulation and VEGF expression in human cervical carcinoma and hepatoma cells," Molecular Cancer Therapeutics, vol. 5, no. 5, pp. 1227-1238, 2006.

[93] Z. Wang, C. Jiang, W. Chen et al., "Baicalein induces apoptosis and autophagy via endoplasmic reticulum stress in hepatocellular carcinoma cells," BioMed Research International, vol. 2014, Article ID 732516, 13 pages, 2014.

[94] Y.-W. Chiu, T.-H. Lin, W.-S. Huang et al., "Baicalein inhibits the migration and invasive properties of human hepatoma cells," Toxicology and Applied Pharmacology, vol. 255, no. 3, pp. 316326, 2011.

[95] H.-M. Kuo, H.-C. Tsai, Y.-L. Lin et al., "Mitochondrialdependent caspase activation pathway is involved in baicaleininduced apoptosis in human hepatoma J5 cells," International Journal of Oncology, vol. 35, no. 4, pp. 717-724, 2009.

[96] W.-H. Chang, C.-H. Chen, and F.-J. Lu, "Different effects of baicalein, baicalin and wogonin on mitochondrial function, glutathione content and cell cycle progression in human hepatoma cell lines," Planta Medica, vol. 68, no. 2, pp. 128-132, 2002.

[97] Y. Hu, Y. Yang, Q.-D. You et al., "Oroxylin A induced apoptosis of human hepatocellular carcinoma cell line HepG2 was involved in its antitumor activity," Biochemical and Biophysical Research Communications, vol. 351, no. 2, pp. 521-527, 2006.

[98] S.-D. Wang, B.-C. Chen, S.-T. Kao, C.-J. Liu, and C.-C. Yeh, "Genistein inhibits tumor invasion by suppressing multiple signal transduction pathways in human hepatocellular carcinoma cells," BMC Complementary and Alternative Medicine, vol. 14, article 26, 2014.

[99] Y. Ma, J. Wang, L. Liu et al., "Genistein potentiates the effect of arsenic trioxide against human hepatocellular carcinoma: role of Akt and nuclear factor- $\kappa \mathrm{B}$," Cancer Letters, vol. 301, no. 1, pp. 75-84, 2011.

[100] S.-C. Fang, C.-L. Hsu, H.-T. Lin, and G.-C. Yen, "Anticancer effects of flavonoid derivatives isolated from Millettia reticulata 
benth in sk-hep-1 human hepatocellular carcinoma cells," Journal of Agricultural and Food Chemistry, vol. 58, no. 2, pp. 814$820,2010$.

[101] H. Jiang, Y. Ma, X. Chen et al., "Genistein synergizes with arsenic trioxide to suppress human hepatocellular carcinoma," Cancer Science, vol. 101, no. 4, pp. 975-983, 2010.

[102] C.-H. Chen, T.-S. Huang, C.-H. Wong et al., "Synergistic anticancer effect of baicalein and silymarin on human hepatoma HepG2 cells," Food and Chemical Toxicology, vol. 47, no. 3, pp. 638-644, 2009.

[103] L. Su, X. Chen, J. Wu et al., "Galangin inhibits proliferation of hepatocellular carcinoma cells by inducing endoplasmic reticulum stress," Food and Chemical Toxicology, vol. 62, pp. 810-816, 2013.

[104] H.-T. Zhang, H. Luo, J. Wu et al., "Galangin induces apoptosis of hepatocellular carcinoma cells via the mitochondrial pathway," World Journal of Gastroenterology, vol. 16, no. 27, pp. 3377-3384, 2010.

[105] J.-L. Zhao, J. Zhao, and H.-J. Jiao, "Synergistic growthsuppressive effects of quercetin and cisplatin on HepG2 human hepatocellular carcinoma cells," Applied Biochemistry and Biotechnology, vol. 172, no. 2, pp. 784-791, 2014.

[106] V. R. Vásquez-Garzón, J. R. MacIas-Pérez, M. N. JiménezGarcía, V. Villegas, S. Fattel-Fazenta, and S. Villa-Treviño, "The chemopreventive capacity of quercetin to induce programmed cell death in hepatocarcinogenesis," Toxicologic Pathology, vol. 41, no. 6, pp. 857-865, 2013.

[107] J. Zhou, L. Fang, W.-X. Yao et al., "Effect of quercetin on heat shock protein expression in human hepatocellular carcinoma HepG2 cells determined by SILAC," Chinese Journal of Oncology, vol. 33, no. 10, pp. 737-741, 2011.

[108] A. B. Granado-Serrano, M. A. Martín, L. Bravo, L. Goya, and S. Ramos, "Quercetin modulates NF-kappa B and AP1 /JNK pathways to induce cell death in human hepatoma cells," Nutrition and Cancer, vol. 62, no. 3, pp. 390-401, 2010.

[109] Y.-F. Chang, Y.-C. Hsu, H.-F. Hung et al., "Quercetin induces oxidative stress and potentiates the apoptotic action of 2methoxyestradiol in human hepatoma cells," Nutrition and Cancer, vol. 61, no. 5, pp. 735-745, 2009.

[110] J. Y. Kim, E. H. Kim, S. S. Park, J. H. Lim, T. K. Kwon, and K. S. Choi, "Quercetin sensitizes human hepatoma cells to TRAIL-induced apoptosis via Sp1-mediated DR5 up-regulation

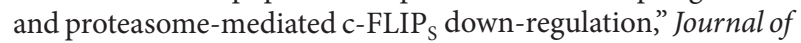
Cellular Biochemistry, vol. 105, no. 6, pp. 1386-1398, 2008.

[111] W. Cui, F. Gu, and K.-Q. Hu, "Effects and mechanisms of silibinin on human hepatocellular carcinoma xenografts in nude mice," World Journal of Gastroenterology, vol. 15, no. 16, pp. 1943-1950, 2009.

[112] P. García-Maceira and J. Mateo, "Silibinin inhibits hypoxiainducible factor- $1 \alpha$ and $\mathrm{mTOR} / \mathrm{p} 70 \mathrm{~S} 6 \mathrm{~K} / 4 \mathrm{E}-\mathrm{BP} 1$ signalling pathway in human cervical and hepatoma cancer cells: implications for anticancer therapy," Oncogene, vol. 28, no. 3, pp. 313-324, 2009.

[113] J. J. Lah, W. Cui, and K.-Q. Hu, "Effects and mechanisms of silibinin on human hepatoma cell lines," World Journal of Gastroenterology, vol. 13, no. 40, pp. 5299-5305, 2007.

[114] L. Varghese, C. Agarwal, A. Tyagi, R. P. Singh, and R. Agarwal, "Silibinin efficacy against human hepatocellular carcinoma," Clinical Cancer Research, vol. 11, no. 23, pp. 8441-8448, 2005.

[115] V. Crespy and G. Williamson, "A review of the health effects of green tea catechins in in vivo animal models," Journal of Nutrition, vol. 134, no. 12, supplement, pp. 3431S-3440S, 2004.
[116] G. Z. Yang, Z. J. Wang, F. Bai et al., "Epigallocatechin-3-gallate protects HUVECs from $\mathrm{PM}_{2.5}$-induced oxidative stress injury by activating critical antioxidant pathways," Molecules, vol. 20, no. 4, pp. 6626-6639, 2015.

[117] M. Nihal, N. Ahmad, H. Mukhtar, and G. S. Wood, "Antiproliferative and proapoptotic effects of (-)-epigallocatechin3-gallate on human melanoma: possible implications for the chemoprevention of melanoma," International Journal of Cancer, vol. 114, no. 4, pp. 513-521, 2005.

[118] H. S. Lee, J.-H. Jun, E.-H. Jung, B. A. Koo, and Y. S. Kim, "Epigalloccatechin-3-gallate inhibits ocular neovascularization and vascular permeability in human retinal pigment epithelial and human retinal microvascular endothelial cells via suppression of MMP-9 and VEGF activation," Molecules, vol. 19, no. 8, pp. 12150-12172, 2014.

[119] M. S. Baliga, S. Meleth, and S. K. Katiyar, "Growth inhibitory and antimetastatic effect of green tea polyphenols on metastasis-specific mouse mammary carcinoma $4 \mathrm{~T} 1$ cells in vitro and in vivo systems," Clinical Cancer Research, vol. 11, no. 5, pp. 1918-1927, 2005.

[120] J.-I. Sonoda, R. Ikeda, Y. Baba et al., "Green tea catechin, epigallocatechin-3-gallate, attenuates the cell viability of human non-small-cell lung cancer A549 cells via reducing Bcl-xL expression," Experimental and Therapeutic Medicine, vol. 8, no. 1, pp. 59-63, 2014.

[121] D. Zhang, M. Al-Hendy, G. Richard-Davis, V. MontgomeryRice, V. Rajaratnam, and A. Al-Hendy, "Antiproliferative and proapoptotic effects of epigallocatechin gallate on human leiomyoma cells," Fertility and Sterility, vol. 94, no. 5, pp. 18871893, 2010.

[122] C. Mayr, A. Wagner, D. Neureiter et al., "The green tea catechin epigallocatechin gallate induces cell cycle arrest and shows potential synergism with cisplatin in biliary tract cancer cells," BMC Complementary and Alternative Medicine, vol. 15, article 194, 2015.

[123] B. N. Singh, S. Shankar, and R. K. Srivastava, "Green tea catechin, epigallocatechin-3-gallate (EGCG): mechanisms, perspectives and clinical applications," Biochemical Pharmacology, vol. 82, no. 12, pp. 1807-1821, 2011.

[124] H. Mukhtar and N. Ahmad, "Tea polyphenols: prevention of cancer and optimizing health," The American Journal of Clinical Nutrition, vol. 71, no. 6, supplement, pp. 1698S-1704S, 2000.

[125] M. Shimizu and I. B. Weinstein, "Modulation of signal transduction by tea catechins and related phytochemicals," Mutation Research: Fundamental and Molecular Mechanisms of Mutagenesis, vol. 591, no. 1-2, pp. 147-160, 2005.

[126] M. Shimizu, A. Deguchi, J. T. E. Lim, H. Moriwaki, L. Kopelovich, and I. B. Weinstein, "(-)-Epigallocatechin gallate and polyphenon $\mathrm{E}$ inhibit growth and activation of the epidermal growth factor receptor and human epidermal growth factor receptor-2 signaling pathways in human colon cancer cells," Clinical Cancer Research, vol. 11, no. 7, pp. 2735-2746, 2005.

[127] M. Masuda, M. Suzui, J. T. E. Lim, and I. B. Weinstein, "Epigallocatechin-3-gallate inhibits activation of HER-2/neu and downstream signaling pathways in human head and neck and breast carcinoma cells," Clinical Cancer Research, vol. 9, no. 9, pp. 3486-3491, 2003.

[128] V. M. Adhami, I. A. Siddiqui, N. Ahmad, S. Gupta, and H. Mukhtar, "Oral consumption of green tea polyphenols inhibits insulin-like growth factor-I-induced signaling in an autochthonous mouse model of prostate cancer," Cancer Research, vol. 64, no. 23, pp. 8715-8722, 2004. 
[129] Y. D. Jung, M. S. Kim, B. A. Shin et al., "EGCG, a major component of green tea, inhibits tumour growth by inhibiting VEGF induction in human colon carcinoma cells," British Journal of Cancer, vol. 84, no. 6, pp. 844-850, 2001.

[130] G. Basini, F. Bianco, and F. Grasselli, "EGCG, a major component of green tea, inhibits VEGF production by swine granulosa cells," BioFactors, vol. 23, no. 1, pp. 25-33, 2005.

[131] S. Shankar, S. Ganapathy, S. R. Hingorani, and R. K. Srivastava, "EGCG inhibits growth, invasion, angiogenesis and metastasis of pancreatic cancer," Frontiers in Bioscience, vol. 13, no. 2, pp. 440-452, 2008.

[132] T. Sen, S. Moulik, A. Dutta et al., "Multifunctional effect of epigallocatechin-3-gallate (EGCG) in downregulation of gelatinase-A (MMP-2) in human breast cancer cell line MCF7," Life Sciences, vol. 84, no. 7-8, pp. 194-204, 2009.

[133] S. K. Denduluri, O. Idowu, Z. Wang et al., "Insulin-like growth factor (IGF) signaling in tumorigenesis and the development of cancer drug resistance," Genes \& Diseases, vol. 2, no. 1, pp. 13-25, 2015.

[134] B. B. Aggarwal, G. Sethi, S. A. Kwang et al., "Targeting signaltransducer-and-activator-of-transcription-3 for prevention and therapy of cancer: modern target but ancient solution," Annals of the New York Academy of Sciences, vol. 1091, pp. 151-169, 2006.

[135] D. G. Hardie, "Molecular pathways: is AMPK a friend or a foe in cancer?" Clinical Cancer Research, vol. 21, no. 17, pp. 3836-3840, 2015.

[136] R. Kaufmann, S. Rahn, K. Pollrich et al., “Thrombin-mediated hepatocellular carcinoma cell migration: cooperative action via proteinase-activated receptors 1 and 4," Journal of Cellular Physiology, vol. 211, no. 3, pp. 699-707, 2007.

[137] S.-Y. Sun, N. Hail Jr., and R. Lotan, "Apoptosis as a novel target for cancer chemoprevention," Journal of the National Cancer Institute, vol. 96, no. 9, pp. 662-672, 2004.

[138] X.-P. Chen, S.-Q. He, H.-P. Wang, Y.-Z. Zhao, and W.-G. Zhang, "Expression of TNF-related apoptosis-inducing Ligand receptors and antitumor tumor effects of TNF-related apoptosisinducing Ligand in human hepatocellular carcinoma," World Journal of Gastroenterology, vol. 9, no. 11, pp. 2433-2440, 2003.

[139] D. G. Breckenridge, M. Germain, J. P. Mathai, M. Nguyen, and G. C. Shore, "Regulation of apoptosis by endoplasmic reticulum pathways," Oncogene, vol. 22, no. 53, pp. 8608-8618, 2003.

[140] K. Révész, A. Tütto, and L. Konta, "Effect of green tea flavanols on the functions of the endoplasmic reticulum," Orvosi Hetilap, vol. 148, no. 40, pp. 1903-1907, 2007.

[141] F. Dituri, A. Mazzocca, J. Fernando et al., "Differential inhibition of the TGF- $\beta$ signaling pathway in HCC cells using the small molecule inhibitor LY2157299 and the D10 monoclonal antibody against TGF- $\beta$ receptor type II," PLoS ONE, vol. 8, no. 6, Article ID e67109, 2013.

[142] W. Liu, H. Nakamura, T. Tsujimura et al., "Chemoprevention of spontaneous development of hepatocellular carcinomas in fatty liver Shionogi mice by a cyclooxygenase-2 inhibitor," Cancer Science, vol. 97, no. 8, pp. 768-773, 2006.

[143] M. A. Kern, A. M. Haugg, A. F. Koch et al., "Cyclooxygenase-2 inhibition induces apoptosis signaling via death receptors and mitochondria in hepatocellular carcinoma," Cancer Research, vol. 66, no. 14, pp. 7059-7066, 2006.

[144] D. G. Menter and R. N. DuBois, "Prostaglandins in cancer cell adhesion, migration, and invasion," International Journal of Cell Biology, vol. 2012, Article ID 723419, 21 pages, 2012.
[145] C. Han, G. K. Michalopoulos, and T. Wu, "Prostaglandin E2 receptor EP1 transactivates EGFR/MET receptor tyrosine kinases and enhances invasiveness in human hepatocellular carcinoma cells," Journal of Cellular Physiology, vol. 207, no. 1, pp. 261-270, 2006.

[146] M. W. Roomi, J. C. Monterrey, T. Kalinovsky, M. Rath, and A. Niedzwiecki, "Comparative effects of EGCG, green tea and a nutrient mixture on the patterns of MMP-2 and MMP-9 expression in cancer cell lines," Oncology Reports, vol. 24, no. 3, pp. 747-757, 2010.

[147] K. H. Kim, Y. D. Park, H. Park et al., "Synthesis and biological evaluation of a novel baicalein glycoside as an antiinflammatory agent," European Journal of Pharmacology, vol. 744, pp. 147-156, 2014.

[148] J. Y. Wu, K. T. Chung, Y. W. Liu, F. J. Lu, R. S. Tsai, and C. H. Chen, "Synthesis and biological evaluation of novel C(6) modified baicalein derivatives as antioxidative agents," Journal of Agricultural and Food Chemistry, vol. 56, no. 8, pp. 28382845, 2008.

[149] L. Gao, C. Li, R.-Y. Yang et al., "Ameliorative effects of baicalein in MPTP-induced mouse model of Parkinson's disease: a microarray study," Pharmacology Biochemistry and Behavior, vol. 133, pp. 155-163, 2015.

[150] Y. Huang, S.-Y. Tsang, X. Yao, and Z.-Y. Chen, "Biological properties of baicalein in cardiovascular system," Current Drug Target_Cardiovascular \& Hematological Disorders, vol. 5, no. 2, pp. 177-184, 2005.

[151] A. Ahad, M. Mujeeb, H. Ahsan, and W. A. Siddiqui, "Prophylactic effect of baicalein against renal dysfunction in type 2 diabetic rats," Biochimie, vol. 106, pp. 101-110, 2014.

[152] Y. Zhang, L. Shan, Y. Hua et al., "Baicalein selectively induces apoptosis in activated lymphocytes and ameliorates concanavalin a-induced hepatitis in mice," PLoS ONE, vol. 8, no. 7, Article ID e69592, 2013.

[153] H.-J. Chen, T.-M. Liang, I.-J. Lee, Y.-T. Huang, and Y.-L. Lin, "Scutellariae radix suppresses LPS-induced liver endothelial cell activation and inhibits hepatic stellate cell migration," Journal of Ethnopharmacology, vol. 150, no. 3, pp. 835-842, 2013.

[154] H.-B. Zhang, P. Lu, Q.-Y. Guo, Z.-H. Zhang, and X.-Y. Meng, "Baicalein induces apoptosis in esophageal squamous cell carcinoma cells through modulation of the PI3K/Akt pathway," Oncology Letters, vol. 5, no. 2, pp. 722-728, 2013.

[155] J. Y. Wu, K. W. Tsai, Y. Z. Li et al., "Anti-bladder-tumor effect of Baicalein from Scutellaria baicalensis Georgi and its application in vivo," Evidence-Based Complementary and Alternative Medicine, vol. 2013, Article ID 579751, 12 pages, 2013.

[156] D. H. Kim, M. A. Hossain, Y. J. Kang et al., "Baicalein, an active component of Scutellaria baicalensis Georgi, induces apoptosis in human colon cancer cells and prevents AOM/DSS-induced colon cancer in mice," International Journal of Oncology, vol. 43, no. 5, pp. 1652-1658, 2013.

[157] G. Donald, K. Hertzer, and G. Eibl, "Baicalein—an intriguing therapeutic phytochemical in pancreatic cancer," Current Drug Targets, vol. 13, no. 14, pp. 1772-1776, 2012.

[158] P. Puri and A. Chandra, "Autophagy modulation as a potential therapeutic target for liver diseases," Journal of Clinical and Experimental Hepatology, vol. 4, no. 1, pp. 51-59, 2014.

[159] Y. Y. Zhou, Y. Li, W. Q. Jiang, and L. F. Zhou, "MAPK/JNK signalling: a potential autophagy regulation pathway," Bioscience Reports, vol. 35, no. 3, Article ID e00199, 2015.

[160] F. Wang, J. L. Yang, K. K. Yu et al., "Activation of the NF$\kappa \mathrm{B}$ pathway as a mechanism of alcohol enhanced progression 
and metastasis of human hepatocellular carcinoma," Molecular Cancer, vol. 14, article 10, 2015.

[161] T. Luedde and R. F. Schwabe, "NF- $\kappa$ B in the liver-linking injury, fibrosis and hepatocellular carcinoma," Nature Reviews Gastroenterology \& Hepatology, vol. 8, no. 2, pp. 108-118, 2011.

[162] D.-P. Ou, Y.-M. Tao, F.-Q. Tang, and L.-Y. Yang, “The hepatitis B virus $\mathrm{X}$ protein promotes hepatocellular carcinoma metastasis by upregulation of matrix metalloproteinases," International Journal of Cancer, vol. 120, no. 6, pp. 1208-1214, 2007.

[163] T. Itoh, Y. Hayashi, T. Kanamaru et al., "Clinical significance of urokinase-type plasminogen activator activity in hepatocellular carcinoma," Journal of Gastroenterology and Hepatology, vol. 15, no. 4, pp. 422-430, 2000.

[164] J. Cheng, J. Qi, X.-T. Li et al., "ATRA and genistein synergistically inhibit the metastatic potential of human lung adenocarcinoma cells," International Journal of Clinical and Experimental Medicine, vol. 8, no. 3, pp. 47220-4227, 2015.

[165] DG. Pons, M. Nadal-Serrano, M. Torrens-Mas, J. Oliver, and P. Roca, "The phytoestrogen genistein affects breast cancer cells treatment depending on the ER $\alpha / \mathrm{ER} \beta$ ratio," Journal of Cellular Biochemistry, 2015.

[166] W. Huang, C. Wan, Q. Luo, Z. Huang, and Q. Luo, “Genisteininhibited cancer stem cell-like properties and reduced chemoresistance of gastric cancer," International Journal of Molecular Sciences, vol. 15, no. 3, pp. 3432-3443, 2014.

[167] Y. Luo, S. X. Wang, Z. Q. Zhou et al., "Apoptotic effect of genistein on human colon cancer cells via inhibiting the nuclear factor-kappa B (NF- $\kappa$ B) pathway," Tumor Biology, vol. 35, no. 11, pp. 11483-11488, 2014.

[168] M. N. Dastjerdi, F. Kavoosi, A. Valiani et al., "Inhibitory effect of genistein on PLC/PRF5 hepatocellular carcinoma cell line," International Journal of Preventive Medicine, vol. 6, article 54, 2015.

[169] Y. Wu, L. Zhang, R. Na et al., "Plasma genistein and risk of prostate cancer in Chinese population," International Urology and Nephrology, vol. 47, no. 6, pp. 965-970, 2015.

[170] Y.-S. Li, L.-P. Wu, K.-H. Li et al., "Involvement of nuclear factor $\kappa \mathrm{B}(\mathrm{NF}-\kappa \mathrm{B})$ in the downregulation of cyclo-oxygenase-2 (COX2) by genistein in gastric cancer cells," Journal of International Medical Research, vol. 39, no. 6, pp. 2141-2150, 2011.

[171] M. S. Tsuboy, J. C. Marcarini, A. O. de Souza et al., "Genistein at maximal physiologic serum levels induces G0/G1 arrest in MCF-7 and HB4a cells, but not apoptosis," Journal of Medicinal Food, vol. 17, no. 2, pp. 218-225, 2014.

[172] S. H. Kim, C. W. Kim, S. Y. Jeon, R. E. Go, K. A. Hwang, and K. C. Choi, "Chemopreventive and chemotherapeutic effects of genistein, a soy isoflavone, upon cancer development and progression in preclinical animal models," Laboratory Animal Research, vol. 30, no. 4, pp. 143-150, 2014.

[173] Y. Sun, W. Z. Liu, T. Liu, X. Feng, N. Yang, and H. F. Zhou, "Signaling pathway of MAPK/ERK in cell proliferation, differentiation, migration, senescence and apoptosis," Journal of Receptors and Signal Transduction, 2015.

[174] F. van Zijl, G. Zulehner, M. Petz et al., "Epithelial-mesenchymal transition in hepatocellular carcinoma," Future Oncology, vol. 5, no. 8, pp. 1169-1179, 2009.

[175] M. Ye, Q. Wang, W. Zhang, Z. Li, Y. Wang, and R. Hu, "Oroxylin A exerts anti-inflammatory activity on lipopolysaccharideinduced mouse macrophage via Nrf2/ARE activation," Biochemistry and Cell Biology, vol. 92, no. 5, pp. 337-348, 2014.
[176] S.-C. Ma, J. Du, P. P.-H. But et al., "Antiviral Chinese medicinal herbs against respiratory syncytial virus," Journal of Ethnopharmacology, vol. 79, no. 2, pp. 205-211, 2002.

[177] H.-T. Trinh, E.-H. Joh, H.-Y. Kwak, N.-I. Baek, and D.-H. Kim, "Anti-pruritic effect of baicalin and its metabolites, baicalein and oroxylin A, in mice," Acta Pharmacologica Sinica, vol. 31, no. 6, pp. 718-724, 2010.

[178] D. H. Kim, S. J. Jeon, K. H. Son et al., "Effect of the flavonoid, oroxylin A, on transient cerebral hypoperfusion-induced memory impairment in mice," Pharmacology Biochemistry and Behavior, vol. 85, no. 3, pp. 658-668, 2006.

[179] R. Zhu, G. Zeng, Y. Chen et al., "Oroxylin A accelerates liver regeneration in $\mathrm{CCI}_{4}$-induced acute liver injury mice," PLoS ONE, vol. 8, no. 8, Article ID e71612, 2013.

[180] L. Wei, Q. Dai, Y. Zhou et al., "Oroxylin A sensitizes non-small cell lung cancer cells to anoikis via glucose-deprivation-like mechanisms: c-Src and hexokinase II," Biochimica et Biophysica Acta: General Subjects, vol. 1830, no. 6, pp. 3835-3845, 2013.

[181] L. Wei, Y. Zhou, C. Qiao et al., "Oroxylin A inhibits glycolysisdependent proliferation of human breast cancer via promoting SIRT3-mediated SOD2 transcription and HIF1 $\alpha$ destabilization," Cell Death and Disease, vol. 6, no. 4, Article ID e1714, 2015.

[182] Y. Yang, Y. Hu, H.-Y. Gu et al., "Oroxylin A induces G2/M phase cell-cycle arrest via inhibiting Cdk7-mediated expression of Cdc2/p34 in human gastric carcinoma BGC-823 cells," Journal of Pharmacy and Pharmacology, vol. 60, no. 11, pp. 1459-1463, 2008.

[183] C. Qiao, L. Wei, Q. Dai et al., "UCP2-related mitochondrial pathway participates in oroxylin A-induced apoptosis in human colon cancer cells," Journal of Cellular Physiology, vol. 230, no. 5, pp. 1054-1063, 2015.

[184] H.-N. Li, F.-F. Nie, W. Liu et al., "Apoptosis induction of oroxylin A in human cervical cancer HeLa cell line in vitro and in vivo," Toxicology, vol. 257, no. 1-2, pp. 80-85, 2009.

[185] H. Hui, Y. Chen, H. Yang et al., "Oroxylin A has therapeutic potential in acute myelogenous leukemia by dual effects targeting PPAR $\gamma$ and RXR $\alpha$," International Journal of Cancer, vol. 134, no. 5, pp. 1195-1206, 2014.

[186] X. Meng, D. A. Franklin, J. Dong, and Y. Zhang, "MDM2-p53 pathway in hepatocellular carcinoma," Cancer Research, vol. 74, no. 24, pp. 7161-7167, 2014.

[187] R. Mu, Q. Qi, H. Gu et al., "Involvement of p53 in oroxylin A-induced apoptosis in cancer cells," Molecular Carcinogenesis, vol. 48, no. 12, pp. 1159-1169, 2009.

[188] T. P. T. Cushnie and A. J. Lamb, "Assessment of the antibacterial activity of galangin against 4-quinolone resistant strains of Staphylococcus aureus," Phytomedicine, vol. 13, no. 3, pp. 187-191, 2006.

[189] G. Duthie and P. Morrice, "Antioxidant capacity of flavonoids in hepatic microsomes is not reflected by antioxidant effects in vivo," Oxidative Medicine and Cellular Longevity, vol. 2012, Article ID 165127, 6 pages, 2012.

[190] H. H. Kim, Y. Bae, and S. H. Kim, "Galangin attenuates mast cell-mediated allergic inflammation," Food and Chemical Toxicology, vol. 57, pp. 209-216, 2013.

[191] S. Kumar and K. R. Alagawadi, "Anti-obesity effects of galangin, a pancreatic lipase inhibitor in cafeteria diet fed female rats," Pharmaceutical Biology, vol. 51, no. 5, pp. 607-613, 2013.

[192] S. Li, C. Wu, L. Zhu et al., "By improving regional cortical blood flow, attenuating mitochondrial dysfunction and sequential apoptosis galangin acts as a potential neuroprotective agent 
after acute ischemic stroke," Molecules, vol. 17, no. 11, pp. 1340313423, 2012.

[193] S. Kapoor, "Galangin and its emerging anti-neoplastic effects," Cytotechnology, vol. 65, no. 4, pp. 467-468, 2013.

[194] X. Zhao and J. Zhang, "Inhibitory effect of galangin on DNA topoisomerases in lung cancer cells," Zhong Nan Da Xue Xue Bao Yi Xue Ban, vol. 40, no. 5, pp. 479-485, 2015.

[195] L. Zhu, Q. Luo, J. Bi, J. Ding, S. Ge, and F. Chen, "Galangin inhibits growth of human head and neck squamous carcinoma cells in vitro and in vivo," Chemico-Biological Interactions, vol. 224, pp. 149-156, 2014.

[196] T. J. Murray, X. Yang, and D. H. Sherr, "Growth of a human mammary tumor cell line is blocked by galangin, a naturally occurring bioflavonoid, and is accompanied by downregulation of cyclins D3, E, and A," Breast Cancer Research, vol. 8, no. 2, article R17, 2006.

[197] T. K. Ha, M. E. Kim, J. H. Yoon, S. J. Bae, J. Yeom, and J. S. Lee, "Galangin induces human colon cancer cell death via the mitochondrial dysfunction and caspase-dependent pathway," Experimental Biology and Medicine, vol. 238, no. 9, pp. 10471054, 2013.

[198] H. Huang, A. Y. Chen, Y. Rojanasakul, X. Ye, G. O. Rankin, and Y. C. Chen, "Dietary compounds galangin and myricetin suppress ovarian cancer cell angiogenesis," Journal of Functional Foods, vol. 15, pp. 464-475, 2015.

[199] A. Monasterio, M. C. Urdaci, I. V. Pinchuk, N. López-Moratalla, and J. J. Martínez-Irujo, "Flavonoids induce apoptosis in human leukemia U937 cells through caspase- and caspase-calpaindependent pathways," Nutrition and Cancer, vol. 50, no. 1, pp. 90-100, 2004.

[200] W. Zhang, Y. Lan, Q. Huang, and Z. Hua, "Galangin induces B16F10 melanoma cell apoptosis via mitochondrial pathway and sustained activation of p38 MAPK," Cytotechnology, vol. 65, no. 3, pp. 447-455, 2013.

[201] C. C. Pan, S. Kumar, N. Shah et al., "Endoglin regulation of Smad2 function mediates beclin1 expression and endothelial autophagy," The Journal of Biological Chemistry, vol. 290, no. 24, pp. 14884-14892, 2015.

[202] S. T. Chien, M. D. Shi, Y. C. Lee, C. C. Te, and Y. W. Shih, "Galangin, a novel dietary flavonoid, attenuates metastatic feature via PKC/ERK signaling pathway in TPA-treated liver cancer HepG2 cells," Cancer Cell International, vol. 15, article 15, 2015.

[203] V. S. Rogovskiĭ, N. L. Shimanovskiŭ, and A. I. Matiushin, "Antihypertensive and neuroprotective activity of quercetin and its derivatives," Eksp Klin Farmakol, vol. 75, no. 9, pp. 37-41, 2012.

[204] R. Huang, T. Zhong, and H. Wu, "Quercetin protects against lipopolysaccharide-induced acute lung injury in rats through suppression of inflammation and oxidative stress," Archives of Medical Science, vol. 11, no. 2, pp. 427-432, 2015.

[205] M. Belviranli and N. Okudan, "Well-known antioxidants and newcomers in sport nutrition: coenzyme Q10, quercetin, resveratrol, pterostilbene, pycnogenol and astaxanthin," in Antioxidants in Sport Nutrition, M. Lamprecht, Ed., chapter 5, CRC Press, Boca Raton, Fla, USA, 2015.

[206] A. M. L. Hossion and K. Sasaki, "Novel quercetin glycosides as potent anti-MRSA and anti-VRE agents," Recent Patents on Anti-Infective Drug Discovery, vol. 8, no. 3, pp. 198-205, 2013.

[207] H. M. Eid, A. Nachar, F. Thong, G. Sweeney, and P. S. Haddad, "The molecular basis of the antidiabetic action of quercetin in cultured skeletal muscle cells and hepatocytes," Pharmacognosy Magazine, vol. 11, no. 41, pp. 74-81, 2015.

[208] M. Waseem and S. Parvez, "Neuroprotective activities of curcumin and quercetin with potential relevance to mitochondrial dysfunction induced by oxaliplatin," Protoplasma, 2015.

[209] E. Rajesh, L. S. Sankari, L. Malathi, and J. R. Krupaa, "Naturally occurring products in cancer therapy," Journal of Pharmacy And Bioallied Sciences, vol. 7, supplement 1, pp. S181-S183, 2015.

[210] X. Zhao and J. Zhang, "Mechanisms for quercetin in prevention of lung cancer cell growth and metastasis," Zhong Nan Da Xue Xиe Bao Yi Xue Ban, vol. 40, no. 6, pp. 592-597, 2015.

[211] J.-Y. Zhang, M.-T. Lin, M.-J. Zhou et al., "Combinational treatment of curcumin and quercetin against gastric cancer MGC-803 cells in vitro," Molecules, vol. 20, no. 6, pp. 1152411534, 2015.

[212] M. G. Refolo, R. D’Alessandro, N. Malerba et al., "Anti proliferative and pro apoptotic effects of flavonoid quercetin are mediated by CB1 receptor in human colon cancer cell lines," Journal of Cellular Physiology, vol. 230, no. 12, pp. 2973-2980, 2015.

[213] F. Yang, L. Song, H. Wang, J. Wang, Z. Xu, and N. Xing, "Combination of quercetin and 2-methoxyestradiol enhances inhibition of human prostate cancer LNCaP and PC-3 cells Xenograft tumor growth," PLoS ONE, vol. 10, no. 5, Article ID e0128277, 2015.

[214] J. Zhou, J. Gong, C. Ding, and G. Chen, "Quercetin induces the apoptosis of human ovarian carcinoma cells by upregulating the expression of microRNA-145," Molecular Medicine Reports, vol. 12, no. 2, pp. 3127-3131, 2015.

[215] Y. Hu, S. Wang, X. Wu et al., "Chinese herbal medicine-derived compounds for cancer therapy: a focus on hepatocellular carcinoma," Journal of Ethnopharmacology, vol. 149, no. 3, pp. 601-612, 2013.

[216] V. Vásquez-Garzón, J. Arellanes-Robledo, R. García-Román, D. Aparicio-Rautista, and S. Villa-Treviño, "Inhibition of reactive oxygen species and pre-neoplastic lesions by quercetin through an antioxidant defense mechanism," Free Radical Research, vol. 43, no. 2, pp. 128-137, 2009.

[217] Y.-F. Chang, N.-W. Chi, and J.-J. Wang, "Reactive oxygen species production is involved in quercetin-induced apoptosis in human hepatoma cells," Nutrition and Cancer, vol. 55, no. 2, pp. 201-209, 2006.

[218] S. Öztürk, K. Schleich, and I. N. Lavrik, "Cellular FLICElike inhibitory proteins (c-FLIPs): fine-tuners of life and death decisions," Experimental Cell Research, vol. 318, no. 11, pp. 13241331, 2012.

[219] W. J. Lu, N. P. Lee, S. Fatima, and J. M. Luk, "Heat shock proteins in cancer: signaling pathways, tumor markers and molecular targets in liver malignancy," Protein and Peptide Letters, vol. 16, no. 5, pp. 508-516, 2009.

[220] A. Sharma, A. K. Upadhyay, and M. K. Bhat, "Inhibition of Hsp27 and Hsp40 potentiates 5-fluorouracil and carboplatin mediated cell killing in hepatoma cells," Cancer Biology and Therapy, vol. 8, no. 22, pp. 2106-2113, 2009.

[221] K. Wellington and B. Jarvis, "Silymarin: a review of its clinical properties in the management of hepatic disorders," BioDrugs, vol. 15, no. 7, pp. 465-489, 2001.

[222] R. K. Dhiman and Y. K. Chawla, "Herbal medicines for liver diseases," Digestive Diseases and Sciences, vol. 50, no. 10, pp. 1807-1812, 2005. 
[223] G. Mallikarjuna, S. Dhanalakshmi, R. P. Singh, C. Agarwal, and R. Agarwal, "Silibinin protects against photocarcinogenesis via modulation of cell cycle regulators, mitogen-activated protein kinases, and Akt signaling," Cancer Research, vol. 64, no. 17, pp. 6349-6356, 2004.

[224] X. Wang, E. Gocek, V. Novik, J. S. Harrison, M. Danilenko, and G. P. Studzinski, "Inhibition of Cot1/Tlp2 oncogene in AML cells reduces ERK5 activation and upregulates p27Kip1 concomitant with enhancement of differentiation and cell cycle arrest induced by silibinin and 1,25-dihydroxyvitamin $\mathrm{D}_{3}$," Cell Cycle, vol. 9, no. 22, pp. 4542-4551, 2010.

[225] D. K. Nambiar, P. Rajamani, and R. P. Singh, "Silibinin attenuates ionizing radiation-induced pro-angiogenic response and EMT in prostate cancer cells," Biochemical and Biophysical Research Communications, vol. 456, no. 1, pp. 262-268, 2015.

[226] R. Kumar, G. Deep, and R. Agarwal, "An overview of ultraviolet B radiation-induced skin cancer chemoprevention by silibinin," Current Pharmacology Reports, vol. 1, no. 3, pp. 206-215, 2015.

[227] Z. Liang, Y. Yang, H. Wang et al., "Inhibition of SIRT1 signaling sensitizes the antitumor activity of silybin against human lung adenocarcinoma cells in vitro and in vivo," Molecular Cancer Therapeutics, vol. 13, no. 7, pp. 1860-1872, 2014.

[228] M. B. Pirouzpanah, M. Sabzichi, S. Pirouzpanah, H. Chavoshi, and N. Samadi, "Silibilin-induces apoptosis in breast cancer cells by modulating p53, p21, Bak and Bcl-XL pathways," Asian Pacific Journal of Cancer Prevention, vol. 16, no. 5, pp. 20872092, 2015.

[229] S. Kumar, K. Raina, C. Agarwal, and R. Agarwal, "Silibinin strongly inhibits the growth kinetics of colon cancer stem cellenriched spheroids by modulating interleukin 4/6-mediated survival signals," Oncotarget, vol. 5, no. 13, pp. 4972-4989, 2014.

[230] K. Wu, Z. Ning, J. Zeng et al., "Silibinin inhibits $\beta$-catenin/ZEB1 signaling and suppresses bladder cancer metastasis via dualblocking epithelial-mesenchymal transition and stemness," Cellular Signalling, vol. 25, no. 12, pp. 2625-2633, 2013.

[231] M. Osaki, M. Oshimura, and H. Ito, "PI3K-Akt pathway: its functions and alterations in human cancer," Apoptosis, vol. 9, no. 6, pp. 667-676, 2004.

[232] Z. X. Qiu, S. Zhao, L. Li, and W. M. Li, "Loss of expression of PTEN is associated with worse prognosis in patients with cancer," Asian Pacific Journal of Cancer Prevention, vol. 16, no. 11, pp. 4691-4698, 2015.

[233] X.-L. Chen, J.-P. Fu, J. Shi, P. Wan, H. Cao, and Z.-M. Tang, "CXC195 induces apoptosis and endoplastic reticulum stress in human hepatocellular carcinoma cells by inhibiting the PI3K/Akt/mTOR signaling pathway," Molecular Medicine Reports, vol. 12, no. 6, pp. 8229-8236, 2015.

[234] A. Villanueva, C. Alsinet, K. Yanger et al., "Notch signaling is activated in human hepatocellular carcinoma and induces tumor formation in mice," Gastroenterology, vol. 143, no. 6, pp. 1660.e7-1669.e7, 2012.

[235] R. Ghasemi, S. H. Ghaffari, M. Momeny et al., "Multitargeting and antimetastatic potentials of silibinin in human HepG-2 and PLC/PRF/5 hepatoma cells," Nutrition and Cancer, vol. 65, no. 4, pp. 590-599, 2013.

[236] O. Kucera, V. Mezera, A. Moravcova et al., "In vitro toxicity of epigallocatechin gallate in rat liver mitochondria and hepatocytes," Oxidative Medicine and Cellular Longevity, vol. 2015, Article ID 476180, 10 pages, 2015.

[237] D. Wang, Y. Wang, X. Wan, C. S. Yang, and J. Zhang, "Green tea polyphenol (-)-epigallocatechin-3-gallate triggered hepatotoxicity in mice: responses of major antioxidant enzymes and the Nrf2 rescue pathway," Toxicology and Applied Pharmacology, vol. 283, no. 1, pp. 65-74, 2015.

[238] M. Li, A. Shi, H. Pang et al., "Safety, tolerability, and pharmacokinetics of a single ascending dose of baicalein chewable tablets in healthy subjects," Journal of Ethnopharmacology, vol. 156, pp. 210-215, 2014.

[239] A. B. Siegel, R. Narayan, R. Rodriguez et al., "A phase I dosefinding study of silybin phosphatidylcholine (milk thistle) in patients with advanced hepatocellular carcinoma," Integrative Cancer Therapies, vol. 13, no. 1, pp. 46-53, 2014.

[240] X. Yanyu, S. Yunmei, C. Zhipeng, and P. Qineng, “The preparation of silybin-phospholipid complex and the study on its pharmacokinetics in rats," International Journal of Pharmaceutics, vol. 307, no. 1, pp. 77-82, 2006.

[241] Y. Yun, Y. W. Cho, and K. Park, "Nanoparticles for oral delivery: targeted nanoparticles with peptidic ligands for oral protein delivery," Advanced Drug Delivery Reviews, vol. 65, no. 6, pp. 822-832, 2013.

[242] R.-L. Duan, X. Sun, J. Liu, T. Gong, and Z.-R. Zhang, "Mixed micelles loaded with silybin-polyene phosphatidylcholine complex improve drug solubility," Acta Pharmacologica Sinica, vol. 32, no. 1, pp. 108-115, 2011.

[243] K. A. Khaled, Y. M. El-Sayed, and B. M. Al-Hadiya, “Disposition of the flavonoid quercetin in rats after single intravenous and oral doses," Drug Development and Industrial Pharmacy, vol. 29, no. 4, pp. 397-403, 2003.

[244] A. K. Mandal, D. Ghosh, S. Sarkar, A. Ghosh, S. Swarnakar, and N. Das, "Nanocapsulated quercetin downregulates rat hepatic MMP-13 and controls diethylnitrosamine-induced carcinoma," Nanomedicine, vol. 9, no. 15, pp. 2323-2337, 2014.

[245] F. Dajas, "Life or death: neuroprotective and anticancer effects of quercetin," Journal of Ethnopharmacology, vol. 143, no. 2, pp. 383-396, 2012.

[246] P. Chen, M.-D. Hu, X.-F. Deng, and B. Li, "Genistein reinforces the inhibitory effect of cisplatin on liver cancer recurrence and metastasis after curative hepatectomy," Asian Pacific Journal of Cancer Prevention, vol. 14, no. 2, pp. 759-764, 2013. 


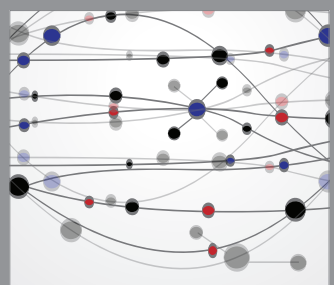

The Scientific World Journal
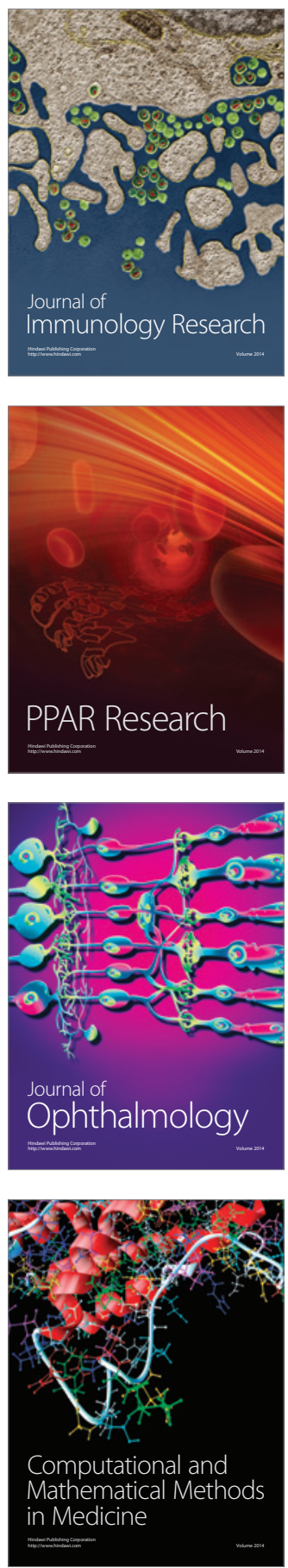

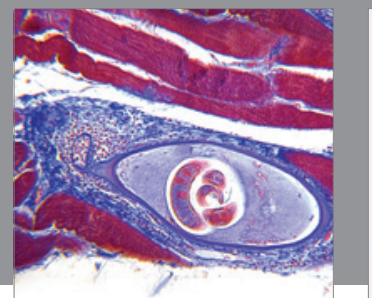

Gastroenterology

Research and Practice
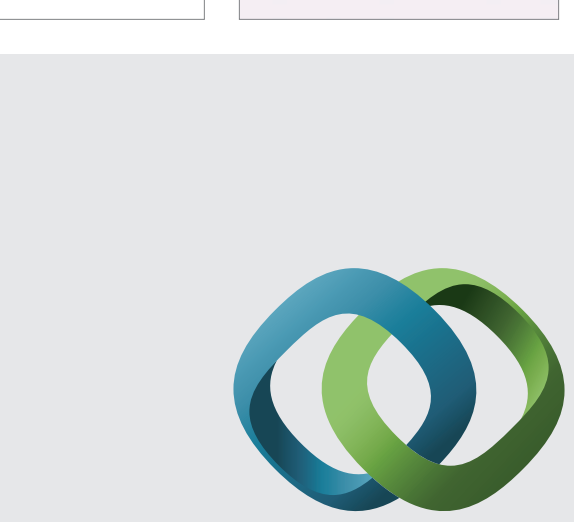

\section{Hindawi}

Submit your manuscripts at

http://www.hindawi.com
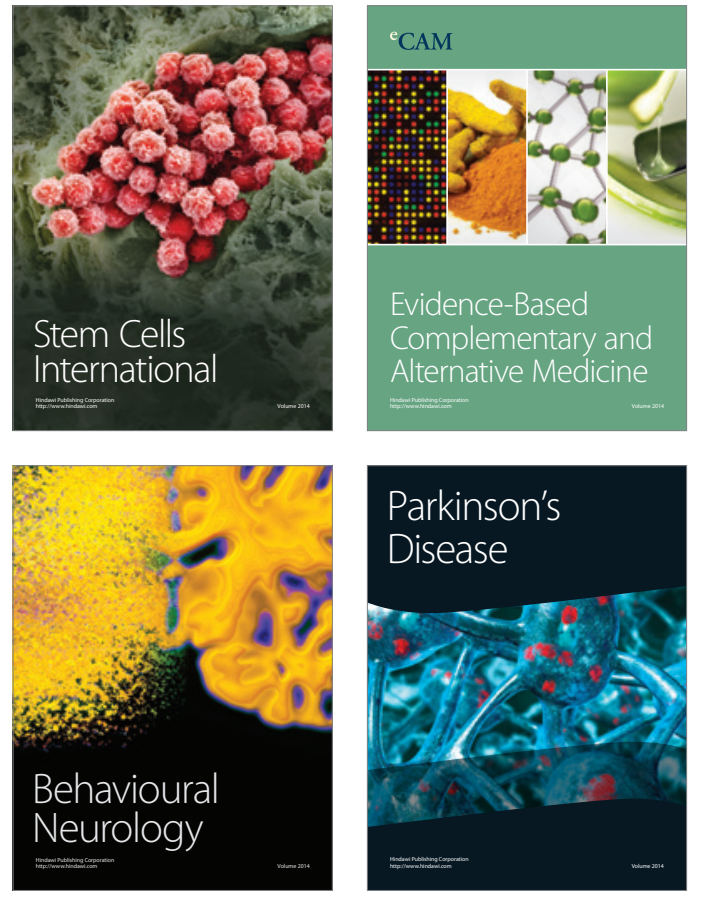
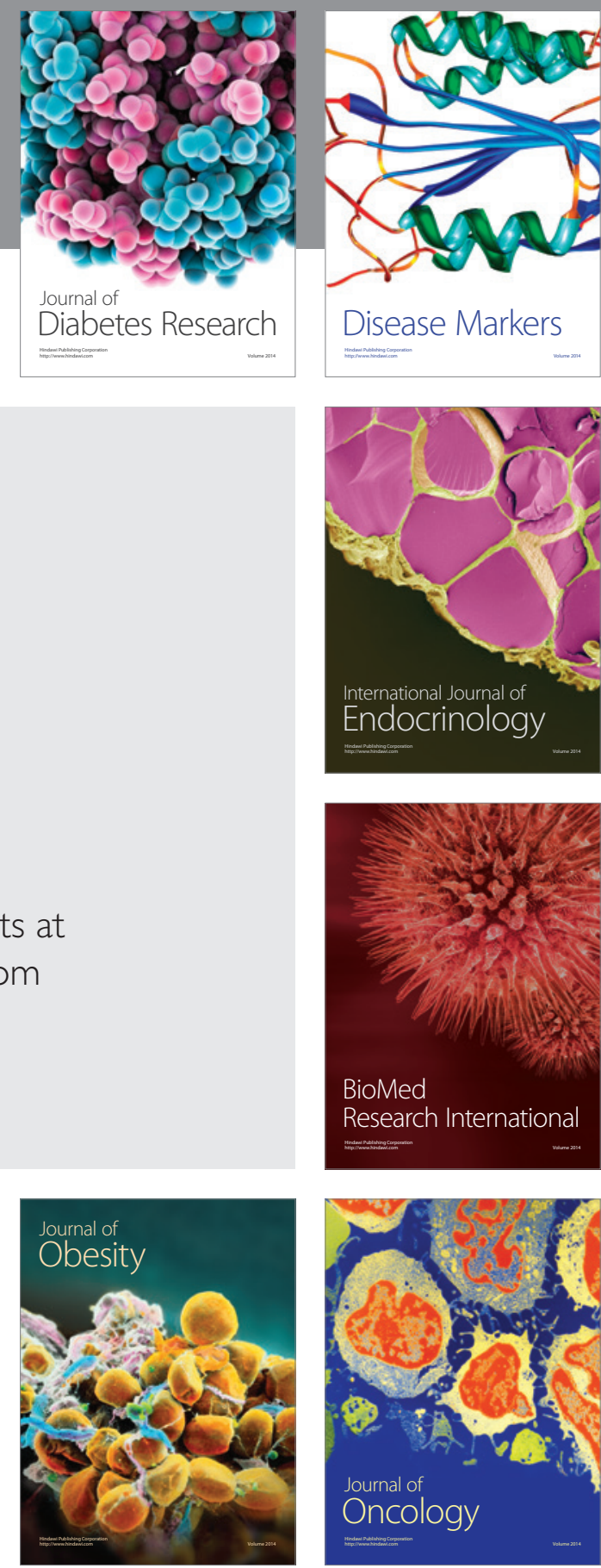

Disease Markers
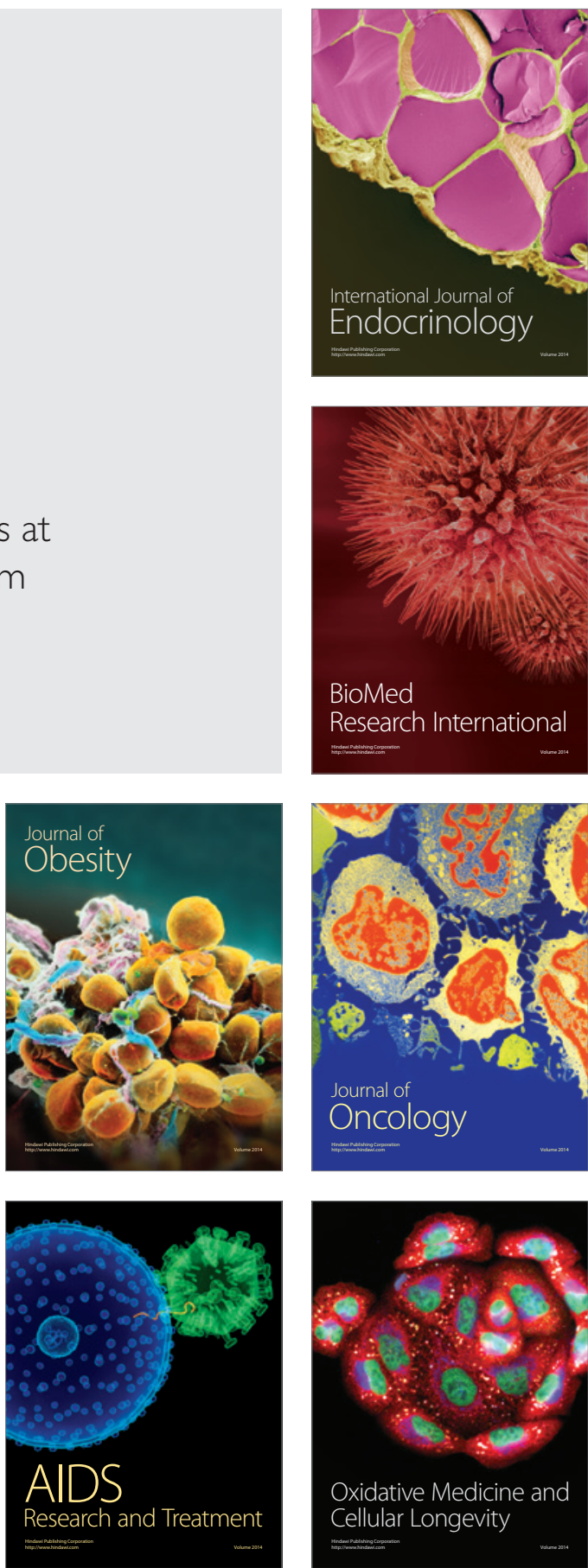